Utah State University

DigitalCommons@USU

$5-1951$

\title{
The Freezing Point of Water in Puddled and Unpuddled Soils at Different Soil Moisture Tension Values
}

Robert B. Campbell

Utah State University

Follow this and additional works at: https://digitalcommons.usu.edu/etd

Part of the Physics Commons, and the Soil Science Commons

\section{Recommended Citation}

Campbell, Robert B., "The Freezing Point of Water in Puddled and Unpuddled Soils at Different Soil Moisture Tension Values" (1951). All Graduate Theses and Dissertations. 4025.

https://digitalcommons.usu.edu/etd/4025

This Thesis is brought to you for free and open access by the Graduate Studies at DigitalCommons@USU. It has been accepted for inclusion in All Graduate Theses and Dissertations by an authorized administrator of DigitalCommons@USU. For more information, please contact digitalcommons@usu.edu.

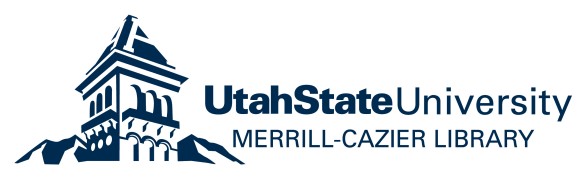


THE MEQZTN POTKT OE WATEA IN PUDDLD AND DUFUDDLED BOTIS AT

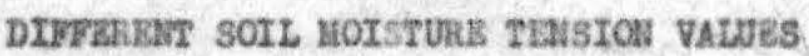

\section{by}

Robert B. Campbell

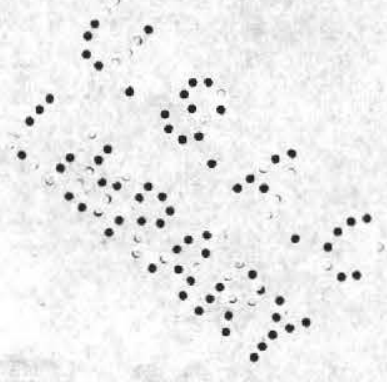

A theels submitted in partial fulfilinent of the requirements for the degree of

Master of Sclence

In

Sol2 Phystes

Utah State Agricultural College

Logan, Utah

1951 


\section{ACKNOWLSDGPSENT}

The experimental data reported here were taken at the U. S. Reglonal Salinity and Rubidoux Laboratories in Riverside, Califormia, under the direction of Dr. L. A. Richards, to whon the author is deeply indebted for much unselfish advice and assistance.

The author also wishes to acknowledge the helprul suggestions made by Dr. S. A. Tayzor. 
TABus of cormens

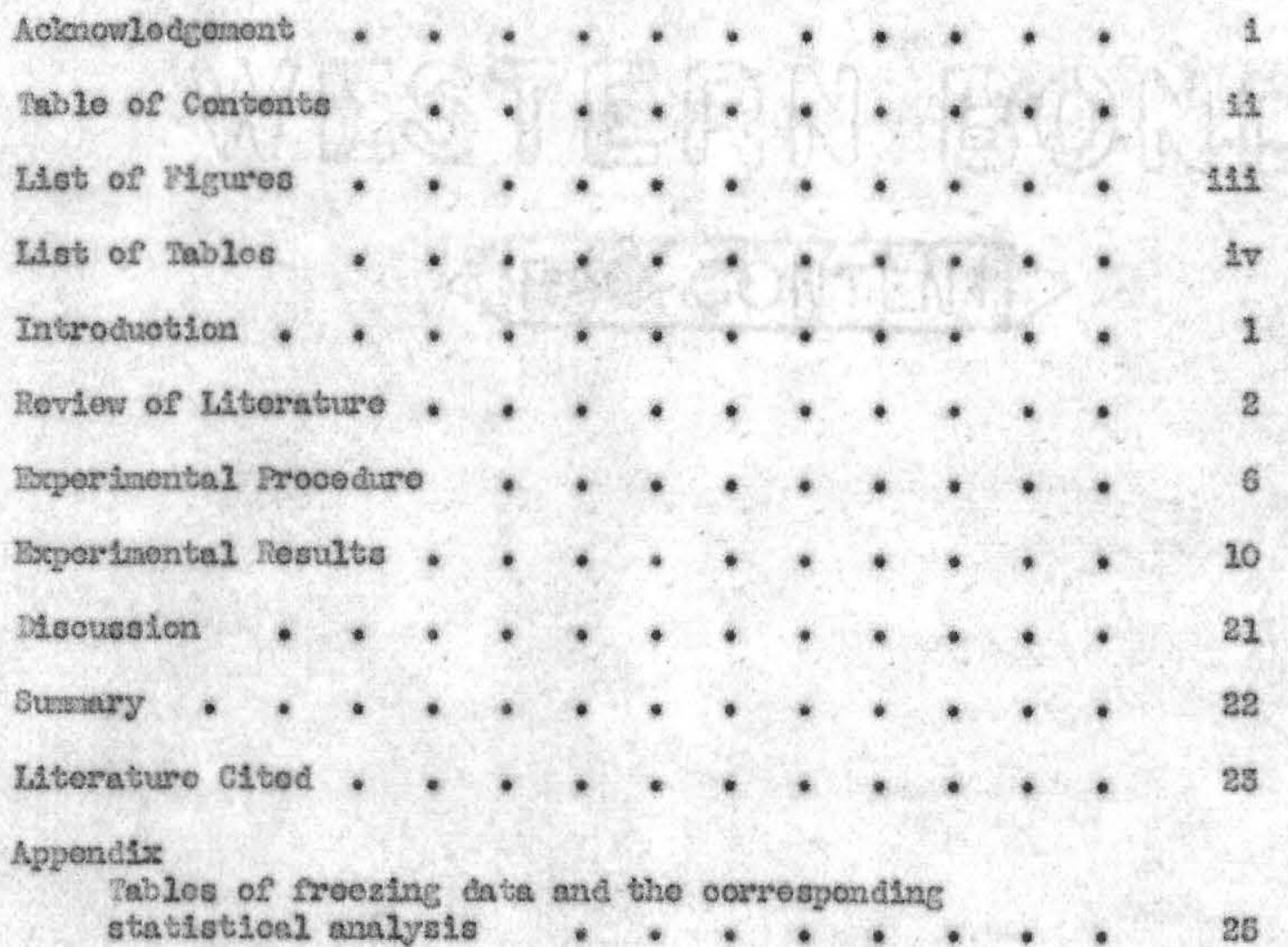


Bare

Pare

1. S012 nolature tenelon ourves for throe eolle in a

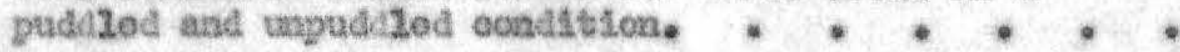

2. Pelation of croesine point dopwosston to noleture

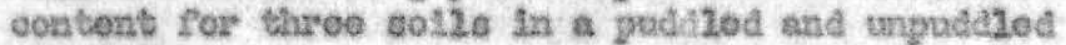
condstotome

3. Bo13 noletrue bonston (Gin) ourves obtalned fron

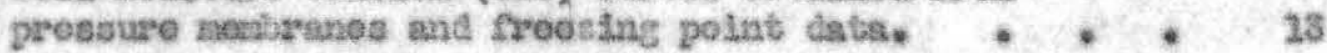

4. Delation of soi 2 nolature tonelen to froosing polnt Gopresstan.

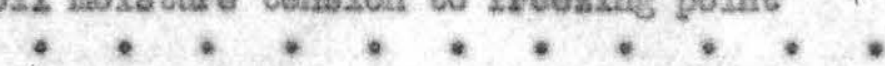

5. fiolation of soll motsture teneloa to froosing polnt

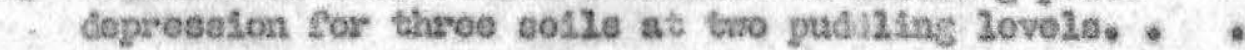

C. Bfroot of altemate freosing and tharing on the freosing potat dogreseten of sulz at $2 / 3$ end 1 atragentere of sol2 motroture tenston.

7. zefoot of altoraste froezing and thawing on the froentng potnt cogresston of aoli at 5 and 25 atunogphoros of ao:2 noluture torastom. 


\section{LISE OF TAMLS}

$\operatorname{Tab} 20$

Page

2. Some salinity and molsture characteristios of

sol.1 seleoted for study.

2. The standard orror, SB, of the freesing neasurenonts at soverral soll moisturo tension lovols. . . . . 20

3. Freesing point resistence dabn for Pachspge Ptne

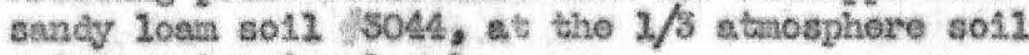
noleture terseton level.

4. Troezing poInt resletance data for Pachappa fino sundy loow sol1. "S044 at the 2 atmosphere sol1 nolsture tenston lovel.

5. Mreesing polnt reatstaneo data for Pachapps fino sandy $10 e n$ soli 3044 at the 5 ataosphere soli notsture tonsion lovel.

6. Freezing point resistance data for Pachappa eine sandy loen so12 3044 at the 15 atzosphere sol1 molsture tenetion lovel.

7. Freesing point reelstance data for Ft, Collins loan so12. Bs at the 1/3 atapsphere soll molsture tenston level.

6. Meosing potnt restetanoe data for Ft. Collins loan 6012 83 at the 1 atrooshere so12 molsture tenston level.

9. Froesing point rasistance data for Ft. Collins Lopt soll I0s at the 5 atrosphero so11 molature tenston leve1.

20. Freezing point resistance data for Tt. Collins loan oo11 / $/ 3$ at the 25 atzosphere soll molsture tonsion 1.vel.

11. Froozing point resigtanco data for Chino olay loam so12 577 at the $1 / 3$ atrooshere coll moloturo tenston level.

12. Freeging point resistanoe data for Chino olay loan soil I377 at the 1 atmosphere soll molsture teneton 2 evol. 
13. Freezing point rosiatence data for Chino elay loam so12 $\$ 377$ at the 5 atmosphore soll molature tonslon lovel.

14. Freesing polnt realstance deta for Chino clay loam soli 5377 at the 25 atnospinere sol2 molature tonsion lovel.

15. Analysis of vartance of froes ing type and suceosalve froeztag wreatrents at the $1 / 3$ acmosghere soll molstaro tension 2evel. . . . . . . . .

16. Aralysis of varlanee of freosing type and euceesstvo froesing treatments at the 1 atzoophore sol. moleture tension levol.

17. Analysis of varianoo of froozing type and suceessive freosing troatuents at the 5 atwogphere soil nolsturo testelon lovel.

18. Amalysis of variance of freezing type and succosstve freesing treatnents at the 25 atmosphere sol. moleture teaston $10 v e 1$.

19. Analysis of variance of troezing type and suocesstve froosing at eaoh sol1 texture, pudiling and molaturo tonelon lovel.

20. Pooled analysis of varlance of eoj.2 tostcure, pudding, freezing type, and auocosstwe freezing treatanents at the $2 / 3$ atmosphere soll molstrure tenston lovel.

22. Pooled analysis of vartanoe of soli toxture, pudding; freesins typo, and sucoessive froesing treatmento at the 1 atmosphore soll nolsture tonsion lovel.

22. Poolod analysis of varianco of soli terture, pudiling, freoning type, and suecossive freosing breatmonts at the 5 atmosphere sol2 molstrure tension 20 vol.

23. Sumary of acalyels of' varlanee whore the error has been pooled for analyste at three sol. molature tenstion Ievols. 


\section{IWTRCDUCTION}

A technique that will adequately deseribe the physicel condition of vater in the soli has long been desired by scientists. The wethod should include the effect of soluble materials on the osmotic pressure of the soil solution, and also the effect of surface force action between the so11 and soll water.

Perker (8) demonstrated that the freezing point wes reduced in the presence of finely divided materisl. This suggested the possibilIty of using the cryoscopie procedure to measure the physical condition of water in sol1. More recently, the introduction of Thermistors for accurate temperature measurenent have made it desirable to investigate in greater detail the freezing point of water in soil.

The experimental work reported here deals with the freezing point of water in soll and its relation to soll molsture tension as determined on three solis in a puddled and unpuddled condition. Several freezing treatments were included in this study to investlgate improvements in the freezing technique. The treatments were arranged in a standard split plot experimental design. Bighteen hundred freezIng mensurements were made and enalyzed statistloally. 


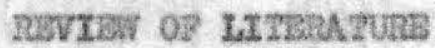

The cryoscopic mothod was used by Bowyoueos and HoCool (4) and later by Foagland ( 7 ) to dotorntine the eoncontration of soluble selte In the so11 solution. At a later date, Partcer (8) dononetrated that PInoly dividod matertal, in the abscaoo of soluble salts, dopressed tho Ireesing point. Since thon, a number of invost1 gators have used the freeatng mothod to determine the condttion of sol1 water in the plant wilting srango and at tho molsture oquivalont.

Partcor (8) doternanod tho freezing polnt of a group of ten solis Lonohed free of soluble salts at the molsture equivalont. These froezIng polnt dopreseion values varled fron 0.043 to 0.75 dogrees centigrace. A convervion of froozing polat doproseton to oquivalont soli molsture stross ydelds a rango of strees valuos from 0.50 to 0.92 atmosphores. Sintlax freostng noasurenents at the molebrure equivalent on a groug of sevon solis wore rade by Bohofield and be costa (25). They found $p$ to vary from 2.52 to 2.96 whlch glvos a range of stress values of fros 0,22 to 0.88 atnosphores. In these monourenonts the Influonce of soluble salts on the froosing point doproeslen of the so12 solution vas not soparatod from sol. molsturo tonston. Botnan and Iny (2) oaloulated the omotie potentlal at the nolsture oquIva-

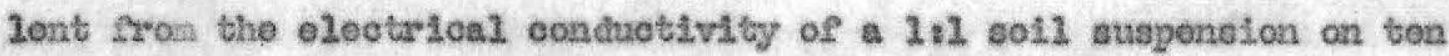
so11a. Thoso osuotic potontlal valuos avoragod $-0.84 x 10^{6}$ arge per gram. The corresponding averago nolsturo potential for these solls was -2.20 sc $10^{6}$ erge por gram. The differomoo betweon average ocmotle potential and averago molsturo potontial ylolds -0.354 a $10^{6}$ ergs per 
gram. This difference converted to soll molsture tension is 0.349 a tmospheres.

A number of investigators $(3,12,14,15,17)$ havo usod freezing point to evaluate the physioal condition of water in soil in the wiltIng range. Richards, Campbell, and Hoalton (13) have sumarized the results of the above authors and have found the freezing point depression values to range from 0.59 to 3.56 degrees contigrade. This corresponds to a soll molsture tension range from 7.1 to 43 atmospheres. Some recont freezing point measurements in the wilting range wore made by Blair, Richards, and Campbe11 (1). These measurements indicate that variability associated with replicates of the same soll sarple was less than the variability between individual soils that ropresent a textural class range.

Schofield and Da Costa recognized that freezing dries the soil, and consequently pF values calculated from freezing point depression correspond to the moisture contents at the time the freezing point is read from the thermometer. Thus, to make a moisture contont correction. for undercooling, they calculated the anount of ice that formed during freezing and subtracted It from the initial moisture content. Bodnan and Day (3) measured the observed freezing point on roplicate samples of Yolo silt loan soll at various undercooling levels and from these freezing measurements plotted an underdooling-freezing point curvo. The amount of ice formed as a result of undercooling during freezing was caloulated in order to obtain a corrected froezing pointmudercooling curve. An inspection of these curves show that at undercooling values greater than three degrees centigrade, the undercooling correction does not keep the corrected freezing point curve invariant with 
respect to undercooling. The failure of the corrected and uncorrected freezing point depression curves to correspond when interpolated to zero undercooling, indicates the inadequacy of this method for calculating the undercooling correction.

The foregoing type of undercooling correction is related to a moisture content change due to ice formed during freezing, but the correction does not account for the concentrating of soluble salt in the soil solution when freezing occurs. In some unpublished undercooling studies $1 /$, it was found, contraxy to expectations, that soil in the 5 to 15 atmosphere soil moisture tension range gave a decrease in freez-

- ing-point depression rather than an increase with increasing undercooling. In these undercooling studies, many of the soils in the low soil moisture tension range gave little or no change in the observed freezing point depression $v i t h$ change in undercooling in an undercooled range from one half to three degrees centigrade. Consequently no undercooling correction has been applied fur freezing point calculations made in this paper.

A sample calculation to indicate the magnitude of the undercooling correction may be made as follows: Take a soil sample in the wilting range that contains 100 grams of dry soll and 6 grams of water, and assume that the sample has been frozen with an undercooling of one degree centigrade. Also assume the specific heat of the 3011 to be .25 calories per gram. The grams of ice formed upon freezing is taken to

1) The undercooling studies connected with freezing point measurements In soil were done by the author at the U.S. Regional Salinity and Rubidoux Laboratories, Riverside, Calif. 
bo $\frac{(100 \times 0.25)+6}{80} \times 1$ which reduces the soli from 6 percont to 5.64 poreent of water. A 0.1 poroont change of vater content in so11 in the wiltine range produced approsinately a one atuosphere ohange In so12 molature stress, as obtalnod from data roported by Richards, Cowpoe12, and Moalton (13). An average soll molsture stross valuo calenlated fron observod freozing polnt doproselon data on 52 solls

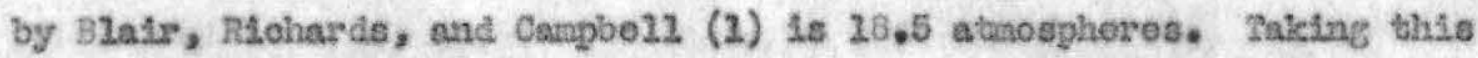
valuo as the soll mo1sture stress corresponding to 5.64 percent, wo caloulate the molsture strese at 6 percent water by subtraoting 3.6 atzosphores from 18.5 to give 36.9 atmospheres.

Douyoucos and HoCool (5) obsorved that the froezing polnt doproselon In soli decrossed whon a sanple was frozen, thamod, and then rofrozen. In a $2 a t e r$ invoatigatioa it was found that sands, burned silioIo aold, and lrovolin doprossed the sreozing point to loasor dogree than elay collo upon ropoated freozing. They reasoned that freezing causes coagulation of tho hyorogels and hydrosols in tho soll and that this coagulation is accompanted by a decrease in the nolsture absorptive powor of solils. Sohorteld and Da Costa (26) have indicated that the difference in freesing point dopressioan boturoon suocosalve freezinga was alininged by wee of thotr froezing procedure " $A^{n}$. This procedure was used to roduce cooling due to the soll surroundings during the freosing process in so13. These authors further suggest that posstbly uyon froczing, 100 erystals produoe oavitioe in the sol.2 which do not roturn to their ortetinal sige upon theving. 
EXPLERIERTAL, PROCEDURE

Three so11 types, whose salinity and nolsture oharaoterieties aro given in tablo 1 , were coleoted to represent a teastural range for mineral soils. The solls were air dried, passed through a 2 ma, rounclhole sievo, and subdsvidod into pint jers. Thus, roplicate sanples were avaliable for the study. One half of the soll sarples were moletened to approstrately Pleld aapaosty and atimed with a rod to obtain a high degree of pudding. These solis vere eaturated with vator and poured on porous nembranes. The unguddled solls vere divided into brass rings on the porous nembranos and were saturated by applying water to the ugper soil surface. Corranto plates (10) wore ueed for the one third to one atzosphore pressure range with collulose meribranes $(2)$ being used for pressures above one atwosphere. The puddled and unpuddled soils were brought to oquilibriun at $1 / 5,3,5$, and 25 atraspheres of pressure. The corresponding froezing points were then dotormined.

Hard rriboer cylindere with plastic oaps sinilar to those cescribed by Richards and Canpbell (12) were ueod as soll contalnors. Coros were cut from the layors of soll on the porous monbranes and insorted into the cylinders. These core contalners wore dropped inte $3 / 4$ Inch glass test trubes closed with a rubber stopper to provent mosature 10ss. Tho sane test tubes wore ineerted into an air jaciset motnted in a freezIng bath as described by Rlchards and Camplell (11).

Five succosaIvo freezinge and thavings woro agde on IIftoen ropIloate core sanples for oach soll at four tonston levels in both a puddled and unpudaled condition. The oores wore thavred in an loe bath 
Table 1,- Some salinity and moisture characteristics of soils selected for study.

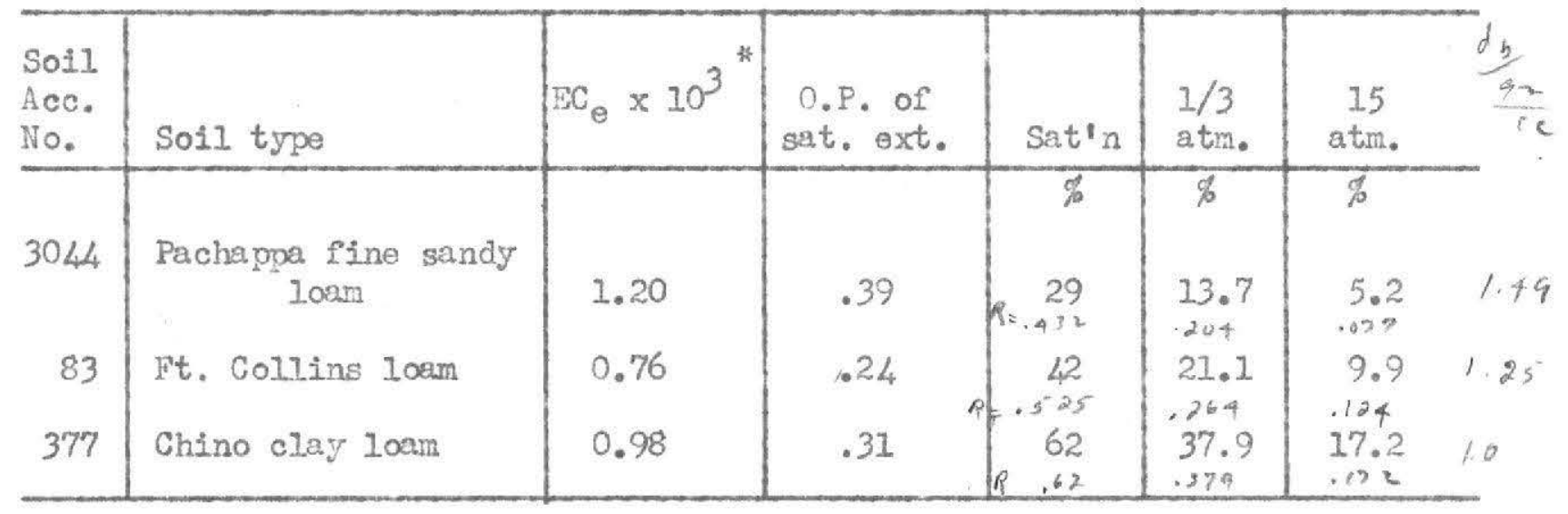

* Electrical conductivity of the saturation extract expressed in millimhos per centimeter.

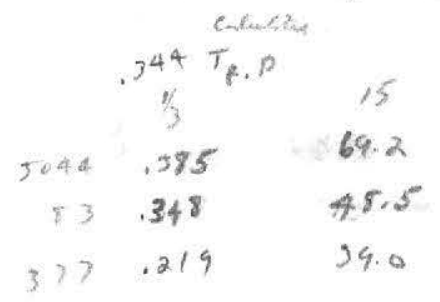


between froesings to minindze the novemont of molsture within the 301. PLfteon cores roprosonting enoh soll at four tonston lovels wore randonizod into throe groups of five cores each. These cores vere subJootod to a "nornal freezo", a "coep freose", and an "adtabatile freezo". In the "normal freese" process, the oores wore undereooled to 2.0 to I.5 degrees centigrado below the expeoted freosing point. Froesing was Inttisted and the texperature maxina observed during freesing rere rooordod and are reforrod to as the observod freestug polnts, Toe The samplos givon the "doep freeze" treatanent wore frogen indtialzy by the "normal frcozo" proceduro and limediately transforred to a deop froezo unit at minus 20 dogrees centigrade. After three hotrs the samples woro transferrod froan the doep froose undt to a bath at zero dogreos cantigrade for thawlig. Al1 subsequont froezlngs of these soll cores wore congleted by the nomal freezing procedure. For the "adiabntio freese" the temperature difference botweon the samplo and its surzoundIngs wae lcopt saall to mAninize heat loss from the sanple during freezIng. To accomplish this, the core was undoreooled approxinately one degree contigrade, freosing was initiated, and the sanplo then transforrod to a bath previously adjusted to the expeoted freesing point. The solls wore seleoted for the experiment on the basle of thesw Iow salt content in ordor to reduce the effect of soluble salts on the freesing point. The magnitude of this effeet is indicated in the osmotle pressure data 1isted in table 1. The osnotic pressure of the 3011 solution was calculated from tho electrieal concrotivity of tho extract obtainod from the saturated soli paste. The extraction of water from the so13 on the porous nombrane was initiated whon the so1. 
moLsture contont approselnatod 1 te saturation porcentage. For the osmotle pressuro caloulation at any tenston levol it has beon assuned that the concontration of the solution in the soli did not olrange durIng the molsture extraotion procoss. In other words, at any tine during tho noisture extraetion the salt contont of the solution in the soll is asounod to be equal to the calt eoncentration in the exstraot. 


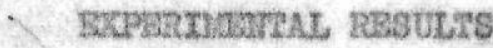

So11 moloturo tension is plotted againgt sol1 moisture contents in f1gure 1. The observod freesing point dopresstion valuos are plottod In figure 2 against the corresponding nolsture porcontages at each soll moleture lovel as given in the first flgure. The ourves in both flgures are hyperbollo in form. To convort freezing polnt depresston values to soli molsture tensien, the osmotie pressure, OP, of the soll solution was subtraoted from the guantity $12.05 \mathrm{x} \Delta_{\mathrm{F}}$. Soll nolsture tension date obtained on the porove membrane syparatus are aleo plotted in PIgure 3.

The relation botween soll nolsture tenslon and the observed froesIng point dopresetion are plotted in flgures 4 and 5. In flgure 4 , the ourve for puldzod soll is shoun adjacent to the corresponding ourve for the ungudaled soll. In flewro 5, the puddiod solls are separated from the unpudelod sol2 treatraents to show difforences between the individual solis vader test. The freezing point depression values for unpuddiod soil wore statistically higher than values whitch were obtainod In puddied soil at ary soll moleture teneion level. Chino clay Low gave anallex froestre-point values than of thor Pachappe rino sandy Loan or Ft. Collins $20 a n$ at correspondine soLil molsture tension lovels. Average obverved freosing-polnt deptesston valuos for sol1 frozen adiabablonly, 1.0., cores frozen in a bath aljusted to the expocted freozing point, wore not atatietically difforont fron values obtained in soil cores frozen by the nornal freezing mothod. To obtain this 


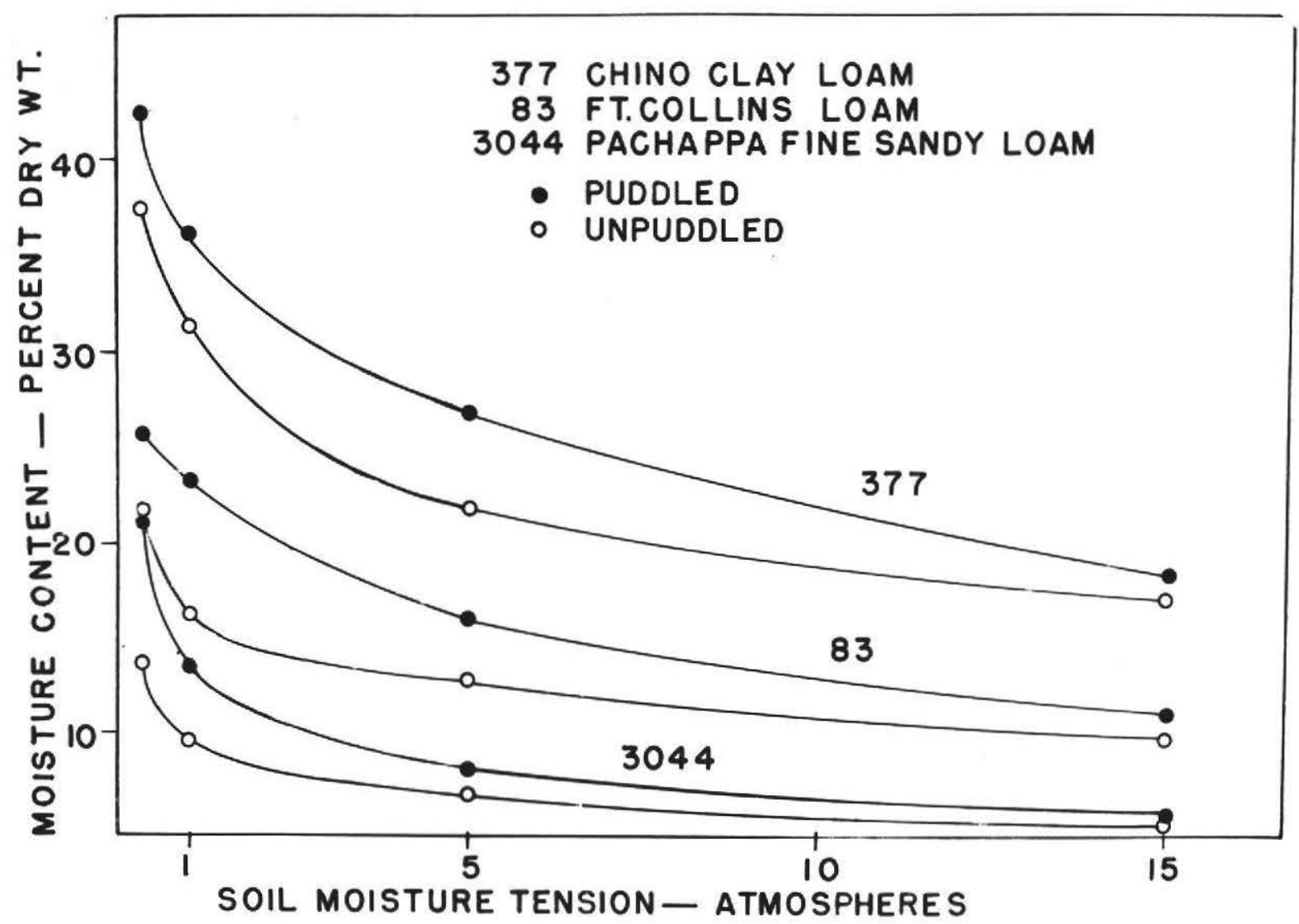

Figure 1. Soll moisture tension curves for three solis in a puddled and unpuddled condition. 


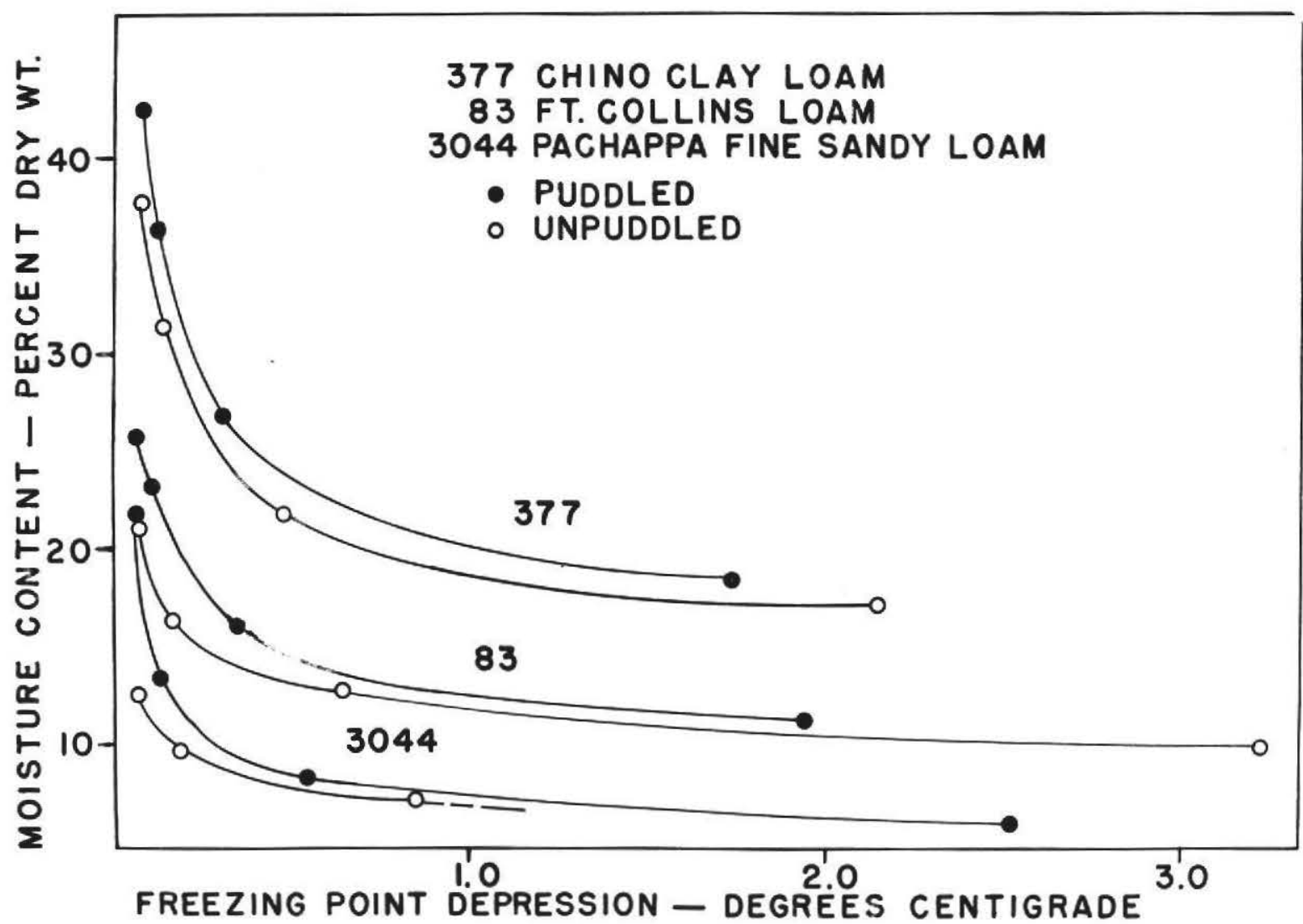

Figure 2. Relation of froezing point depression to moisture content for threo solis in a puddlod and unpudded condition. 


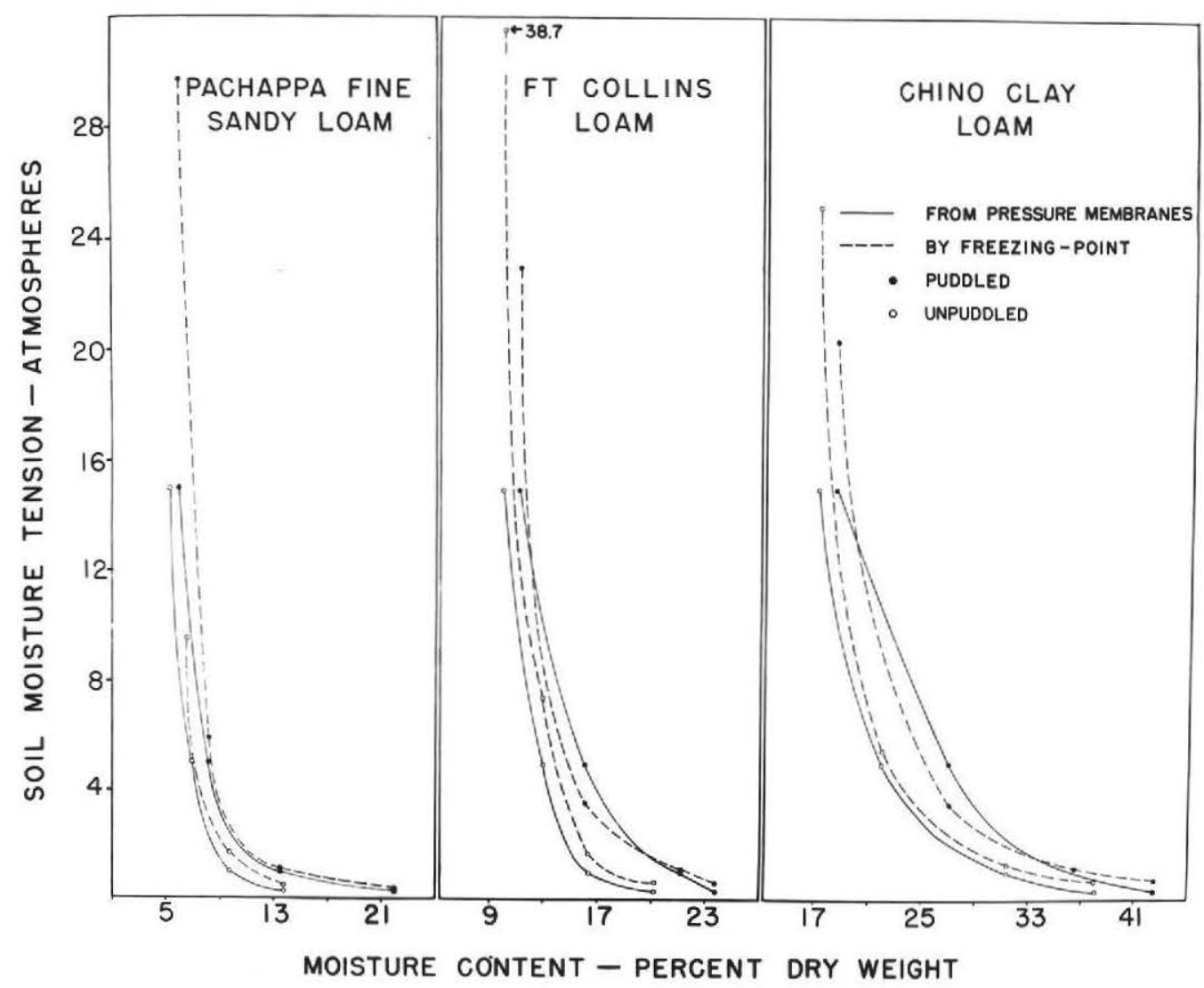

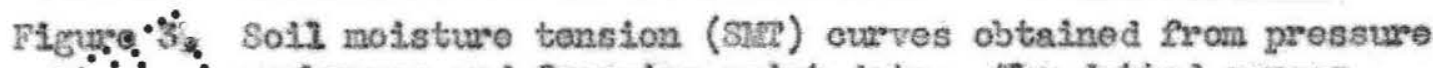
$\therefore \because$ membranes and froezing point data, the dotted ourves

$\therefore \therefore$. $\therefore$ "*re obtained from freezing point values, $\Delta \mathrm{T}_{0}$. as follows: $\because \because \because \because . \because \quad:$ SWT $-12.05 \Delta \mathrm{T}_{0}-0 \mathrm{P}$, where OP Is the osmotic pressure of $\because \because$ the soll solution. 


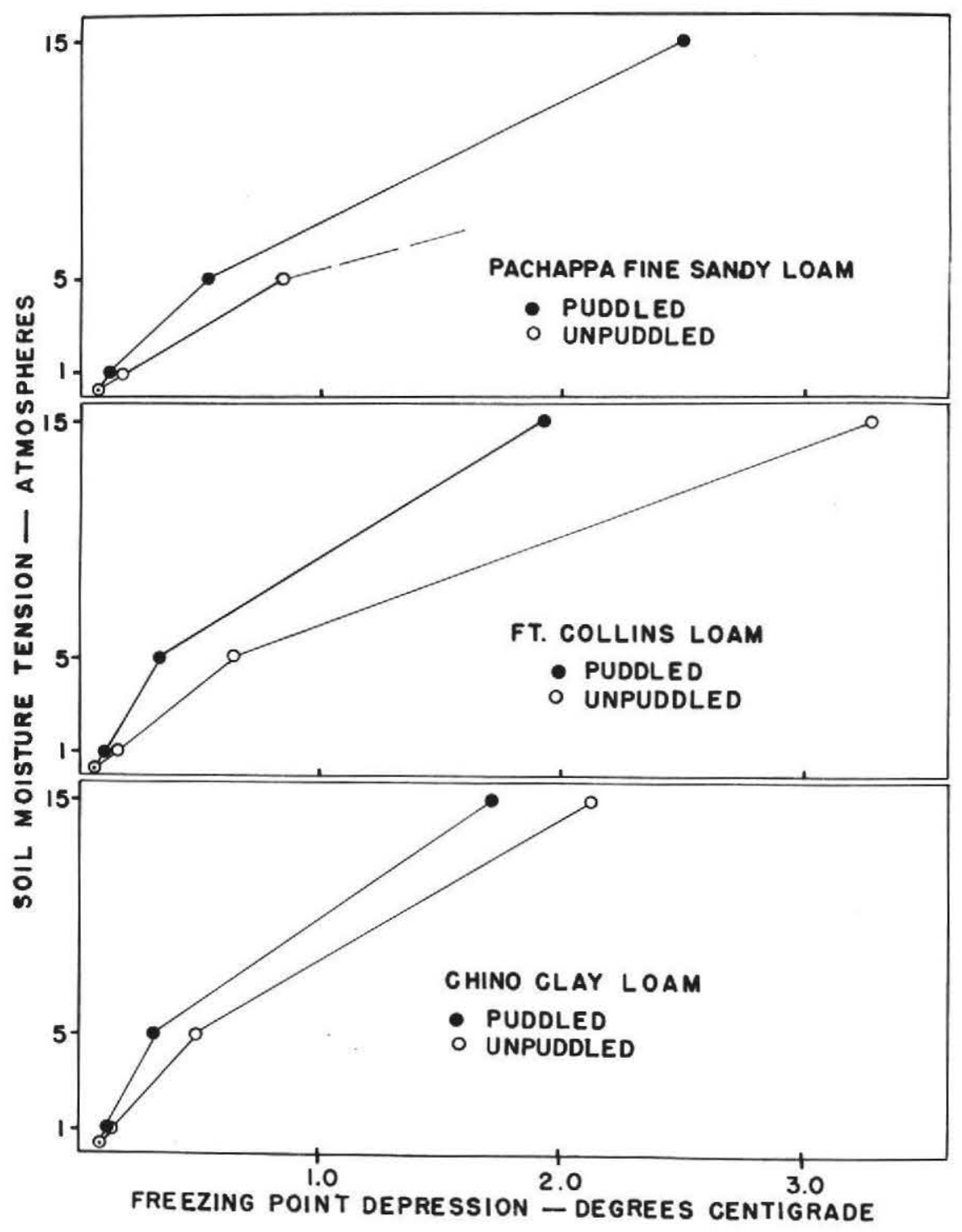

Figure 4. Relation of solil moisture tonsion to freezing point depression. The pudaled sol.1 curves are adjacont to the corresponding unpuddled soll curvos for each soil. 


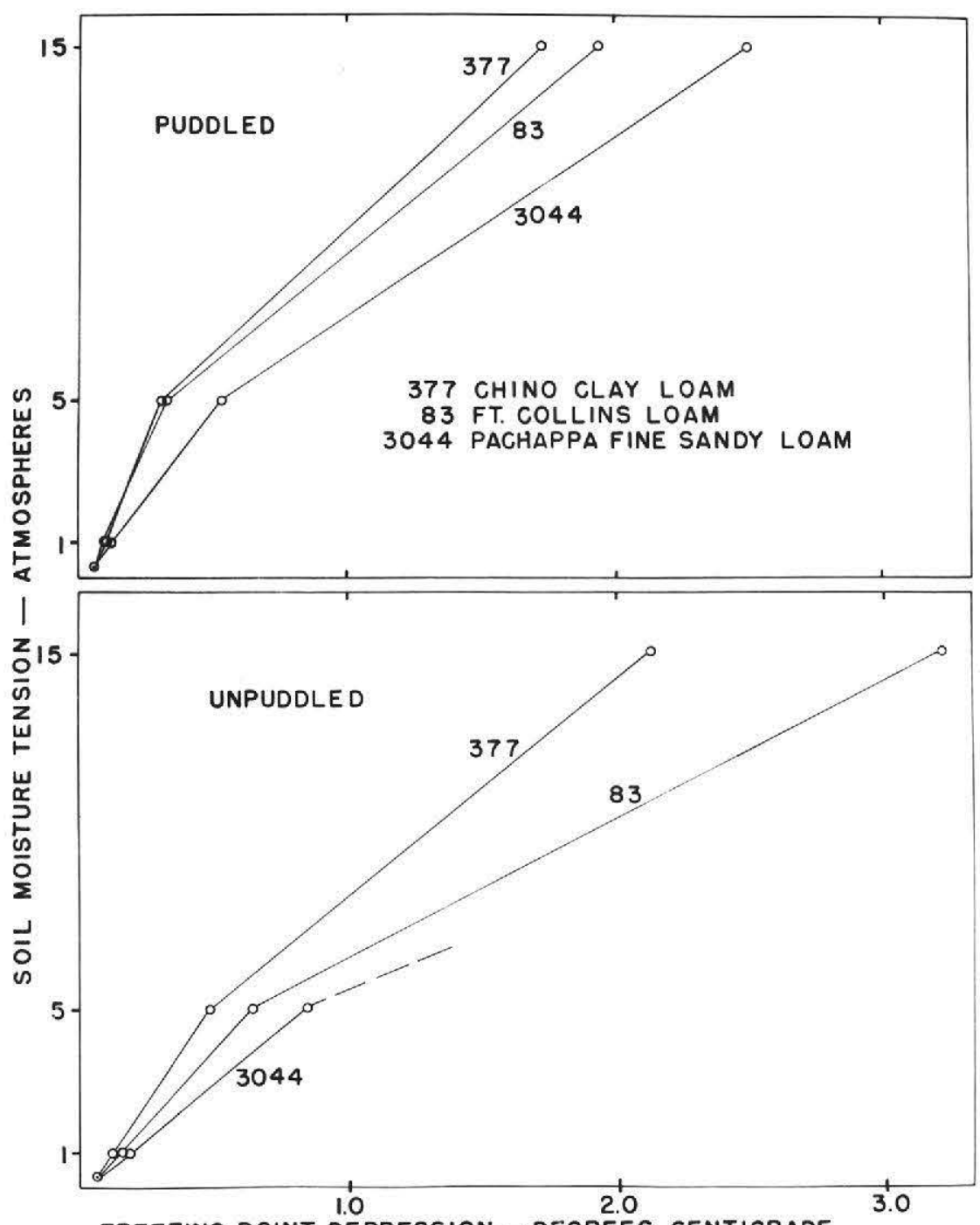

FREEZING POINT DEPRESSION - DEGREES CENTIGRADE

Figure 5. Relation of soli moleture tonsion to freezing point depression for three solis at two pudaling 20vols. 
result, the therral tine constant of the Therristor $2 /$, in water, was about 2 to 4 soconds, which givos an ineliontion of the low themal cempaoity of the terperature-sensitive elenent used to neasure the freozIng point of Boil. Usualiy the tine required to obtain a measurable torperature of the core aurroundinge was 1 to 2 minutes. Thls time dopends mainly upon the thicleness and type of Insulation about the sol1 core and the thornal diffusivity of the soll.

The offeot of alterrate froesing and thawing on the freesing point Coprossion, FP, is seon in Pigures 6 and 7. Larger decreases in the FPD were Qbsorved betweon the first and second successive freezing than botween any other pair of suocessive freezing values, These rosulta are in agrecment with data roported by Bouyoucos and JoCool (5). Sohofield and Da Costa (26), and Brohror and Rose (6). The sosis given the "doop freoze" treatmont gave larger decreasos in the IPD than so1.1e frosen by the norral freozing procedure betwoen the first and second freozing. Thoreafter, these solls gave FPI docreasos that wore noar2y unsforra for the romaining three froesings. One half of the sucoossive freezing curvos terninate with a gradual coorease in sreezing polnt dopression, whereas the ronalning half torninate with no ohange or only a slight inorease in the FPD as a result of repeated froezingse The decrenses in the FPD at the high soll moleture tension lovels wore Greater then at low tenclon lovels.

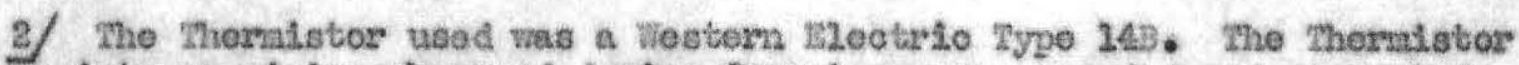
restetenoo minins obsorved during freezing wero reoordod and converted to tomporstures from a proviously coternined celibration ourve. 


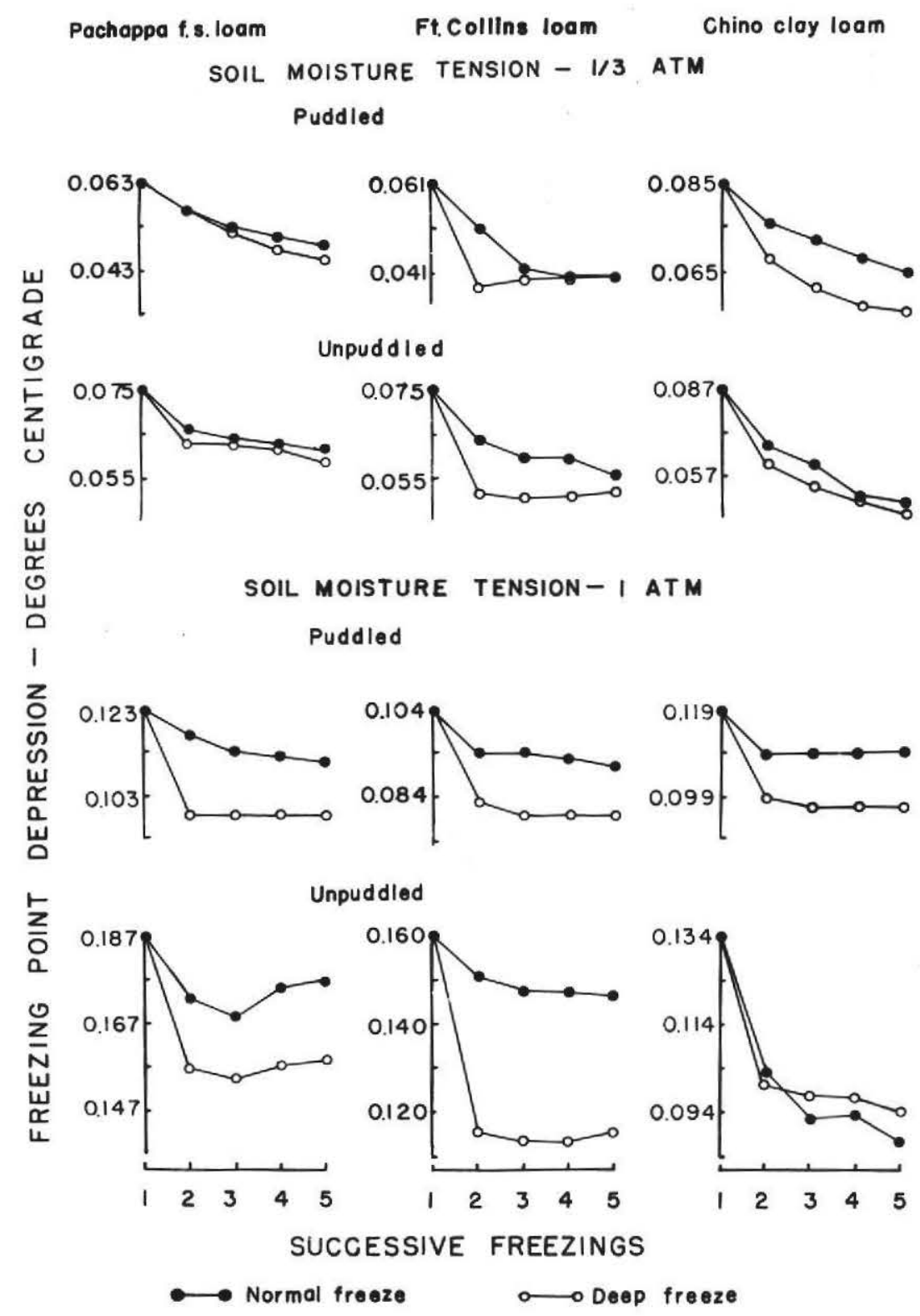

Figure 6. Brfect of altermate freezing and thawing on the freezing point depression of soil at $1 / 3$ and 1 atmosphere of so1. nol.sture tension. 


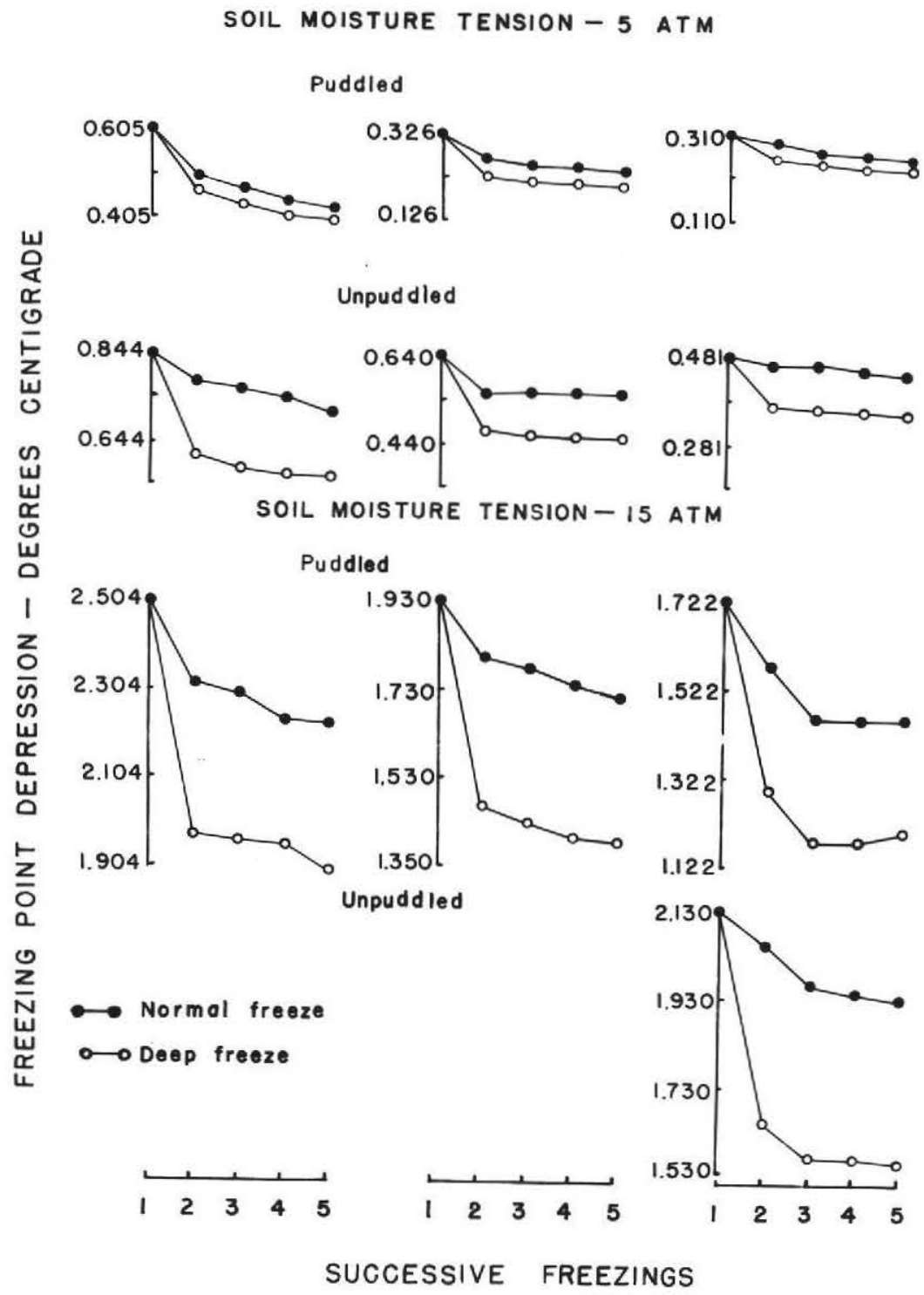

Figure 7. Bffect of alternate froezing and thaving on the freezing point depresston of soil at 5 and 15 atmospheres of sol1 moisture tonsion, 
Tho freesing goint dopreseson valuos and the otandard ozror in degroes ecatigrade for pudaled and unpudaled Chino olay loan, Do. Coll1ns 20as, and Pachappe sonty lom at sovoral sol1 molsture tonston 10vole are givon in tablo 2. The average standard error for the solis tosted over the molsture tenalon ruge constlored here varios betwoen 0.005 and 0.090 dogroos contigrado. Tho coofflelents of varlab1.11ty for so11s In the $2 / 3$ to 25 atwosphero preseure zange vary from 50.9 to 24.4 percent. 
Table 2.--The standard orror, $S E$, of the freezing measurements at several soil moisture tension levels

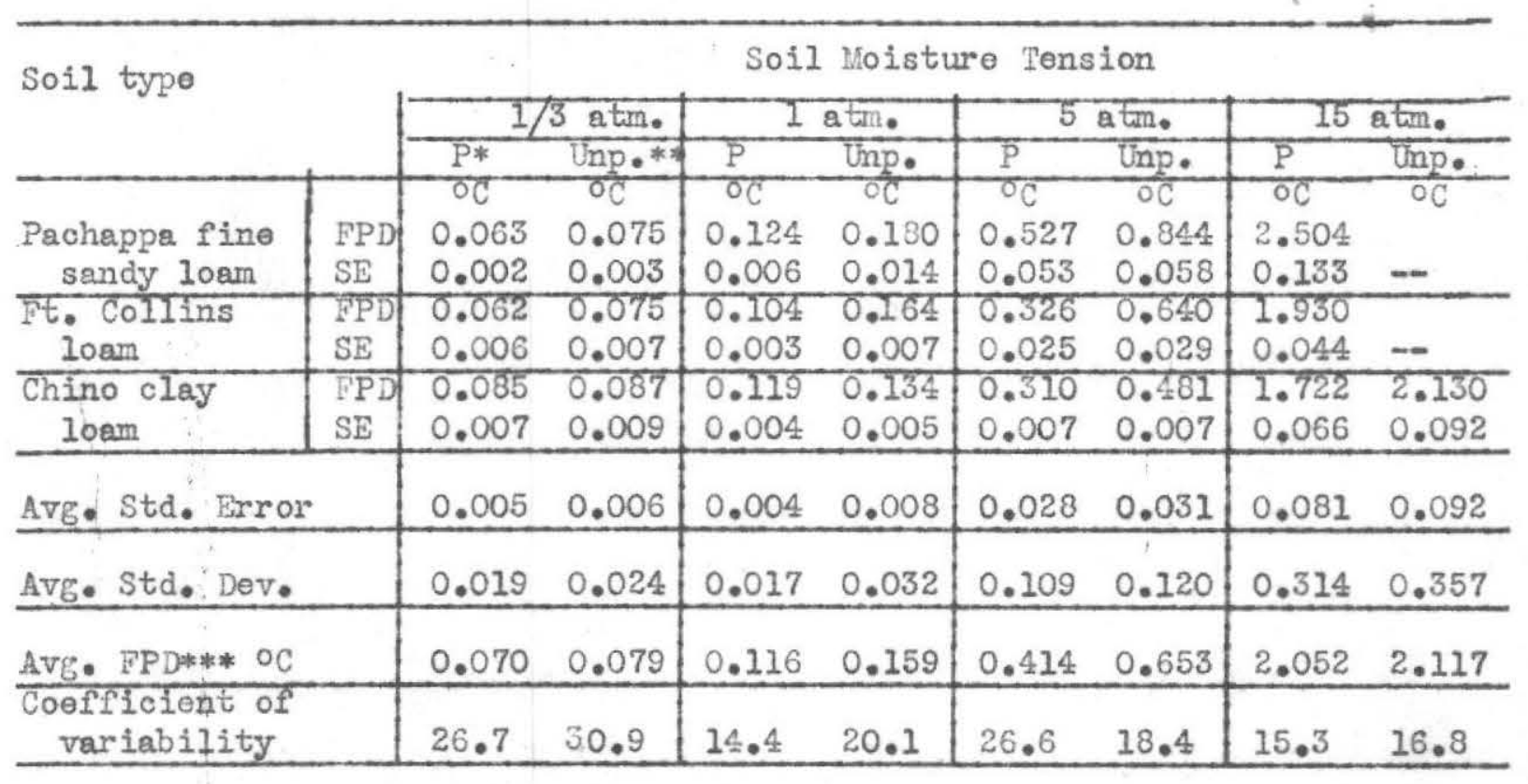

* Puddled soil

** Unpuddled soil

*** FPD $=$ Freezing point depression 


\section{atscussrod}

The difforences botwoon tho caloulated sol1 moleture tonstion ourves and the aotrual soll nolsture tension oturves probably arise from sastantions comneoted with the oanotio pressure caleulation and also from the faot that no uncercooline correotion was nade on the obsorved froezing point dopression. Jyrors from both of these sources tond to Inorease at Low noisture, high teneion levels.

For the experinental toohnique used, the avernge observed froesing point valuos for so1l cores frosen by the nornal freezing nothod at the undereooled temporature were ossontlally the sone as for cores frozen adtabaticaliy in a bath adjusted to the expeotod freezing point. Precautlons acsoetated with the adiabatic freezing technique are made umnecessary by surrounding the soll sample with adoquate therral insulation and by roduoing the hoat capacity and the therrnal lag of the tengerature-sensitive olonont used in the freozing nessureant.

In the successive froezing study it was obsorved that lnrger decreases oocur botween the flrst and socond froesince than betweon any two later froesings. This docroase in the froesing point dopregsion may be due to a deorease in the "mochanioal resistance" of soli. to ine orystal formation. In othor woreds, during later froozings, loe may re-form in eavities that were produced during the oarlier froesings. A3so thore is the possibility that there may ooeur a ohange of soll otruoture which eauses some water to be held less seourely by the soll aftor freezing and thawing. Both of these offects may cause the observed ohenge in freesing point dopression with suocessive freezing. 


\section{SUMUARY}

Pachappa fine sandy Loam, Fort Collins Ioam, and Chino clay loam solis contained higher percentages of water (oven dry basis) at the same soil moisture tension level in a puddled condition than in an unpuddled condition within the soil moisture tengion range up to fifteen atmospheres. These same soils gave freezing point depression values which were larger in the case of a puddled sample than for an unpuddled sample at the same moisture content.

It was found that the average observed freezing point depression values for soil cores frozen by the usual freezing procedure at the undercooled temperature were the same as for cores frozen adiabatically In a bath adjusted to the expected freezing point.

A relationship between soil moisture tension and freezing point depression, $\Delta T_{0}$ is presented. To obtain soil moisture tension values from freezing point depression, the osmotic pressure of the soil solution was subtracted from the quantity $12.05 \times \Delta \mathrm{T}_{0}$.

Larger decreases in the freezing point depression were observed to occur between the flrst and second freezing than between any two later freezings in all the soils under test. 


\section{IITRRATURE CITED}

1. Blair, G. Y., Richards, L. A., and Campbell, R. B. 1950. The rate of elongation of sunflower plants and the freezing point of soll moisture in relation to permanent wilt. Soil Sci. 70:431-439.

2. Bodmen, G. B. and Day, Paul R. 1942. Freezing points of a group of California soils and their extracted clays. Soil Sci. 55:225246.

3. Bodman, G. B. and Day, Paul R. 1937. Thermoelectric method of determining the freezing points of soils. Soil Sci. Soc. Amer. Proc. 2:65-71.

4. Bouyoucos, G. J. and MeCool, M. M. 1915. The freezing point method as a new means of measuring the concentration of the soil solution directly in the soil. Wich. Agr. Expt. Sta. Tech. Bul. 2l.

5. Bouyoucos, G. S. and MeCool, M. M. 1916. Further studies on the freezing point lowering of soils. Mich. Agr. Expt. Sta. Tech. Bul. 31.

6. Buehrer, T. F. and Rose, M. S. 1943. Studies in soil structure V. Bound water in normal and puddled soils. Ariz. Exp. Sta. Tech. Bul. 100.

7. Hoagland, D. R. 1918. The freezing point as an index of variations in the soil solution due to season and crop growth. Jour. Agr. Res. $12: 369-395$.

8. Parker, F. W. 1921. The effect of finely divided material on the freezing point of water, benzene, and nitrobenzene. Jour. Amer. Chem. Soc. 43: 1013-1018.

9. Richards, L. A. 1947. Pressure membrane apparatus - construction and use. Agr. Eng. 28:451-454.

10. Richards, L. A. 1948. Porous plate apparatus for measuring moisture retention and transmission by soil. Soil Sci. 66:105-110.

11. Richards, L. A. and Campbell, R. B. 1948. Use of Thermistars for measuring the freezing point of solutions and soils. Soil Sei. 65: 429-436.

12. Richards, L. A. and Campbe11, R. B. 1948. The freezing point of moisture in soil cores. Soil Sci. Soc. Amer. Proc. 13:71-74. 
13. Rlchards, L. A., Campbell, R. B., and Healton, L. W. 1949. Some freezing point depressions on cores of soil in which cotton and sunflower plants were wilted. Soil Sci. Soc. Amer. Proc. 14:47-50.

14. Robertson, L. S. and Kohnke, Helmut 1946. The pF at the wilting point of several Indiana soils. Soil Sc1. Soc. Amer. Proc. 11:5053.

15. Schofleld, R. K. and Da Costa, J. V. B. 1935. The determination of the $\mathrm{pl}$ at permanent wilting and at the molsture equivalent by the freezing point method. Trans. Third Internat, Cong. Soil Sci. 1:610.

16. Schofleld, R. K, and Da Costa, J. V. B. 1938. The measurement of the pF in soil by freezing point. Jour. Agr. Sci. 28:644-642.

17. Veihmeyer, J. F. and Hendrickson, A. H. 1950. Methods of measuring field capacity and permanent wilting percentages of soils. Soil Sei. $68: 75-94$. 


\section{APPSWIDXX}

Tables of Freosing Polnts and the Corresponding Statistical Analyals.

To stuplify the presentation of the freezing point data and the stettstical analysis of these measurenents the following groug of symols vore adoptied.

So12 Sypos

So1.1 Muriber

Pacheppe ftne sendy loam

Fort Colisns $20 a \mathrm{~m}$

Chino olay loan

3044

83

377

So11 treatunont abbrevistitons:

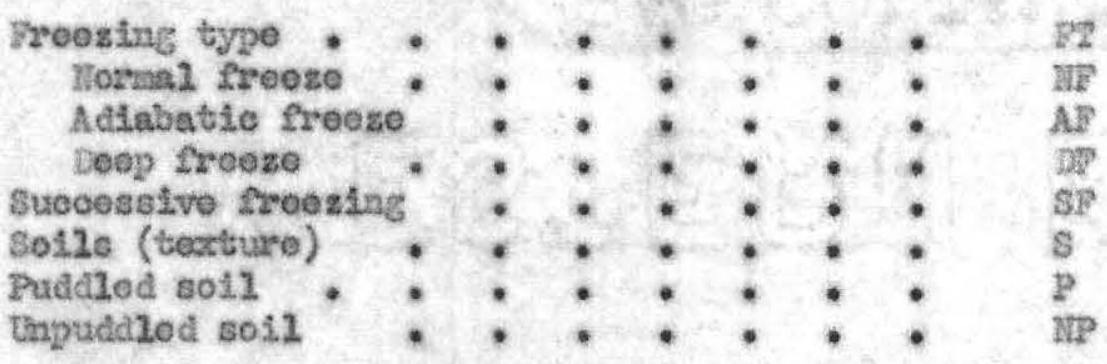

MLsce1lanoous abbreviationg:

So12 moleture tonston (atmosphores) - . Stat Iroosing potnt dopresston (degroos contigrado) IPD Freoutng point reatetance (olns) *. . IPR signifionice at 5j/ probability lovel * * * Stgnirieanoo at 1\% probability lovol . * * 
Table 3. Treczing point resistance da for Pachappa fine sandy loam soil " 3044, at the $1 / 3$ atmosphere soil moisture tension level.

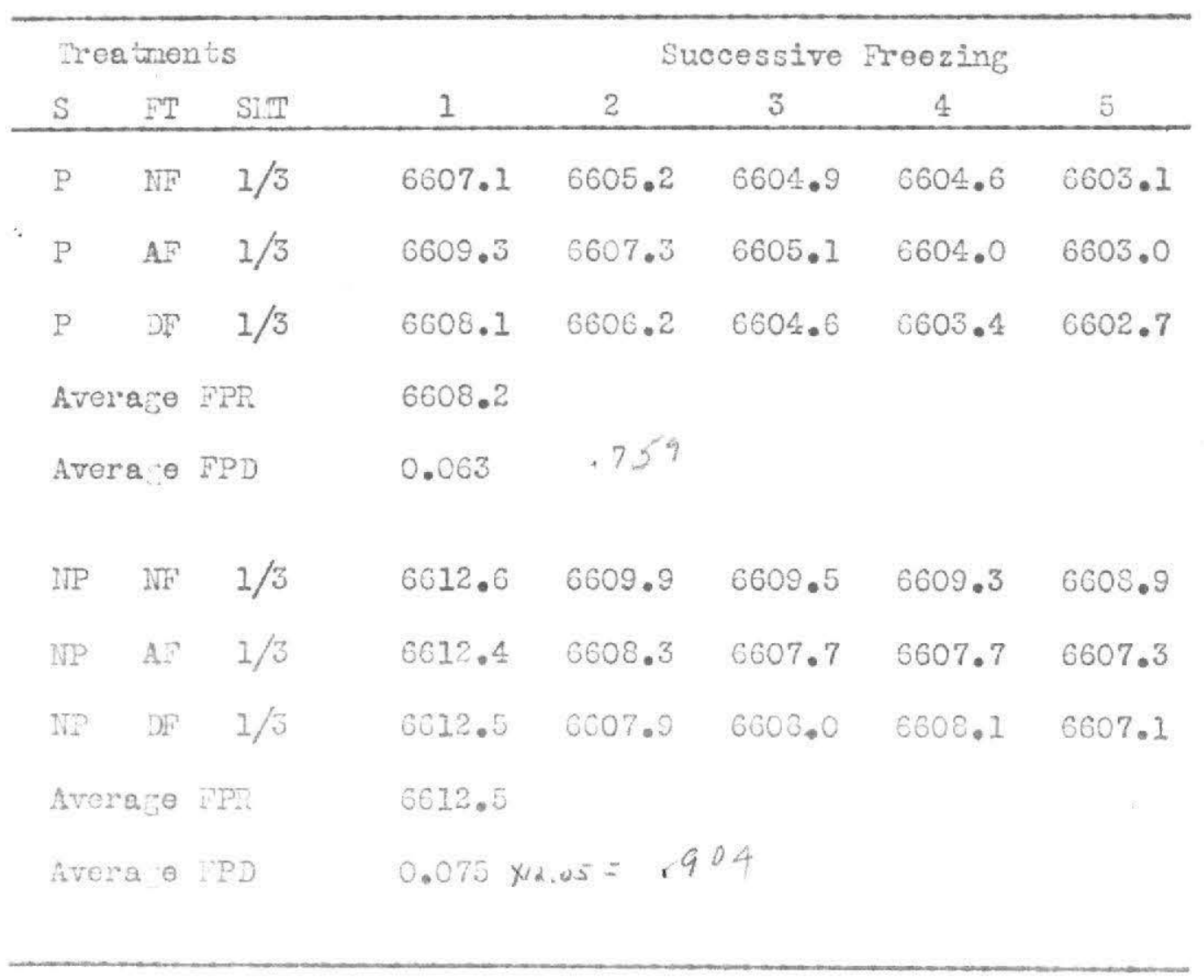


Table 4. Treozing point resistanco data for Pachappa fino sandy loam soil 3044 at the 1 atmosphere soil noisture tension levol.

\begin{tabular}{|c|c|c|c|c|c|c|c|}
\hline \multicolumn{4}{|c|}{ Treatments } & \multicolumn{4}{|c|}{ Succossive Freezing } \\
\hline S & $\mathrm{PT}$ & SIIT & 1 & 2 & 3 & 4 & $\underline{5}$ \\
\hline P & $\mathrm{MF}$ & 1 & 6626.5 & 6625.3 & 6623.0 & 6623.6 & 6622.7 \\
\hline$P$ & $\mathrm{AF}$ & 1 & 6626.6 & 6623.6 & 6623.1 & $6622 \cdot 1$ & 6622.6 \\
\hline P & DF & 1 & 6627.9 & 6620.0 & 6619.9 & 6620.1 & 6620.1 \\
\hline \multicolumn{2}{|c|}{ Average } & FPR & 6627.0 & & & & \\
\hline \multicolumn{2}{|c|}{ Average } & $\mathrm{BPD}$ & 0.124 & 1.49 & & & \\
\hline INP & IVF & 1 & 6641.7 & 6636.6 & 6636.1 & 6636.8 & 6636.1 \\
\hline$i N$ & $\mathrm{AT}^{\mathrm{T}}$ & 1 & 6644.8 & 6640.7 & 6638.3 & 6641.1 & 6641.2 \\
\hline $\operatorname{MP}$ & DF & 1 & $66 \leq 3.0$ & 6634.0 & 6633.2 & 6634.1 & 6634.4 \\
\hline Aver & age & $F P R$ & 6643.2 & & & & \\
\hline Aver & ajo & FPD & 0.130 & 2.169 & & & \\
\hline
\end{tabular}


Table 5. Freezing point resistance date for Pachappa fine sandy loam soil 3044 at the 5 atmosphere soil moisture tension level.

\begin{tabular}{|c|c|c|c|c|c|c|c|}
\hline \multicolumn{3}{|c|}{ Treatments } & \multicolumn{5}{|c|}{ Successive Freezing } \\
\hline $\mathrm{S}$ & FT & SMT & 1 & 2 & 3 & 4 & 5 \\
\hline $\mathrm{P}$ & NF & 5 & 6731.9 & 6702.2 & 6693.2 & 6685.0 & 6679.9 \\
\hline$p$ & $\mathrm{AF}$ & 5 & 6747.0 & 6710.6 & 6701.3 & 6694.5 & 6688.7 \\
\hline$P$ & $D F$ & 5 & 6762.3 & 6716.1 & 6706.1 & 6700.8 & 6697.6 \\
\hline \multicolumn{2}{|c|}{ Average } & FPR & 6747.1 & \multirow{2}{*}{\multicolumn{2}{|c|}{6.35}} & & v \\
\hline \multicolumn{2}{|c|}{ Âverage } & FPD & 0.527 & & & & \\
\hline NP & $\mathrm{NF}$ & 5 & 6841.9 & 6827.8 & 6827.0 & 6817.7 & 6805.2 \\
\hline NP & $\mathrm{AF}$ & 5 & 6840.9 & 6814.8 & 6806.9 & 6797.8 & 6788.5 \\
\hline NP & $D F$ & 5 & 6852.0 & 6776.3 & 6765.7 & 6761.3 & 6759.7 \\
\hline \multicolumn{2}{|c|}{ Average } & FPR & 6844.9 & & & & \\
\hline \multicolumn{2}{|c|}{ Average } & FPD & 0.844 & 10.17 & & & \\
\hline
\end{tabular}


Table 6. Freezing point resistance data for Pachappa fine sandy loam soil 3044 at the 15 atmosphere soil noisture tension level.

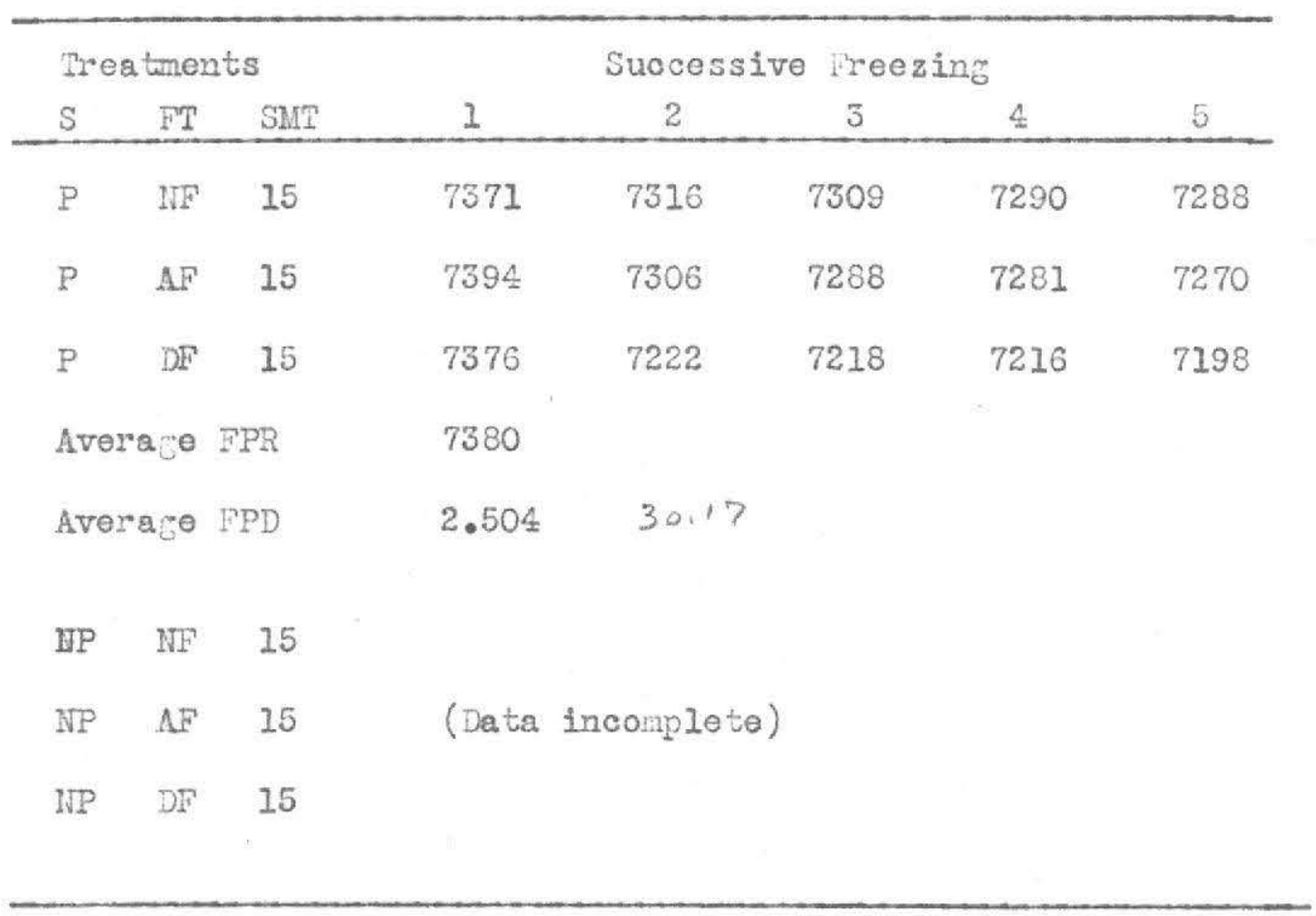


Table 7. Freezing point resistance data for Ft. Collins loan soil 83 at the $1 / 3$ atmosphere soil moisture tension lovel.

\begin{tabular}{|c|c|c|c|c|c|c|c|}
\hline \multicolumn{3}{|c|}{ ireaments } & \multicolumn{5}{|c|}{ Successive Freozing } \\
\hline S & $\mathrm{FT}$ & SNT & 1 & 2 & 3 & 4 & 5 \\
\hline P & MF & $1 / 3$ & $6609 \cdot 2$ & 6605.2 & 6602.0 & 6601.2 & 6601.3 \\
\hline p & $\mathrm{AF}$ & $1 / 3$ & 6607.6 & 6604.9 & 6602.4 & 6602.0 & 6601.9 \\
\hline$P$ & $D F$ & $1 / 3$ & 6606.3 & 6599.2 & 6599.8 & 6599.8 & 6599.8 \\
\hline \multicolumn{2}{|c|}{ Avera } & FRR & 6607.9 & & & & \\
\hline \multicolumn{2}{|c|}{ Average } & EPD & 0.063 & \multicolumn{2}{|c|}{.759} & & \\
\hline IIP & $M F$ & $1 / 3$ & 6613.2 & 6607.6 & 6606.3 & 6606.0 & 6605.3 \\
\hline$\because P$ & $\mathrm{AF}$ & $1 / 3$ & 6611.5 & 6620.5 & 6608.0 & 6607.8 & 6606.0 \\
\hline NP & $D F$ & $1 / 3$ & 6612.4 & 6604.8 & 6604.5 & 6604.4 & 6604.7 \\
\hline \multicolumn{2}{|c|}{ Average } & $\mathrm{FPR}$ & 6612.4 & & & & \\
\hline \multicolumn{2}{|c|}{ Averago } & PPD & 0.075 & .904 & & & \\
\hline
\end{tabular}


Table 8. Freozing point resistance data for Ft. Collins loam soil 83 at the 1 atmosphere soil moisture tension level.

\begin{tabular}{|c|c|c|c|c|c|c|c|}
\hline \multicolumn{3}{|c|}{ Treatments } & \multicolumn{5}{|c|}{ Successive Freezing } \\
\hline$S$ & $\mathrm{FT}$ & SLT & 1 & 2 & 3 & 4 & 5 \\
\hline$P$ & $1 N F$ & 1 & 6621.4 & 6617.7 & 6616.3 & 6616.2 & 6615.6 \\
\hline $\mathrm{P}$ & $\mathrm{AF}$ & 1 & 6620.7 & 6617.7 & 6616.9 & 6626.6 & 6615.7 \\
\hline P & $D F$ & 1 & 6621.2 & 6613.2 & 6612.3 & 6612.4 & 6612.4 \\
\hline \multicolumn{2}{|c|}{ Average } & FPR & 6621.1 & & & & \\
\hline \multicolumn{2}{|c|}{ Avera $\theta$} & PPD & 0.104 & \multicolumn{2}{|l|}{1.253} & & \\
\hline $1 P$ & in & 1 & 6638.2 & 6636.5 & 6634.9 & 6634.7 & 6634.6 \\
\hline NP & $A F$ & 1 & 6636.6 & 6632.2 & 6631.6 & 6631.8 & 6631.2 \\
\hline ITP & $D F$ & 1 & 6638.1 & 6623.6 & 6622.8 & 6622.7 & 6623.4 \\
\hline \multicolumn{2}{|c|}{ Averace } & FPR & 6637.6 & & & & \\
\hline \multicolumn{2}{|c|}{ Avera $\theta$} & FPD & 0.164 & 1.976 & & & \\
\hline & & & & & & & \\
\hline
\end{tabular}


Table 9. Freezing point resistance data for Ft. Collins loam soil 83 at the 5 atmosphere soil moisture tension level.

\begin{tabular}{|c|c|c|c|c|c|c|c|}
\hline \multicolumn{3}{|c|}{ Trestments } & \multicolumn{5}{|c|}{ Successive Freezing } \\
\hline S & FT & SIIT & 1 & 2 & 3 & 4 & 5 \\
\hline$P$ & $\mathrm{NF}$ & 5 & 6687.3 & 6670.3 & 6667.1 & 6663.7 & 6663.4 \\
\hline$P$ & $\mathrm{AF}$ & 5 & 6687.0 & 6669.2 & 6664.5 & 6661.7 & 6659.0 \\
\hline $\mathrm{P}$ & $\mathrm{DF}$ & 5 & 6687.0 & 6654.3 & 6650.7 & 6649.6 & 6647.5 \\
\hline \multicolumn{2}{|c|}{ Average } & FPR & 6687.1 & & & & \\
\hline \multicolumn{2}{|c|}{ Average } & FPD & 0.326 & \multicolumn{2}{|c|}{3.93} & & \\
\hline NP & $\sqrt{5}$ & 5 & 6793.6 & 6769.8 & 6771.2 & 6770.2 & 6770.0 \\
\hline NP & $A T$ & 5 & 6783.2 & 6757.0 & 6754.7 & 6753.4 & 6752.2 \\
\hline NP & $\mathrm{DF}$ & 5 & 6768.1 & 6712.4 & 6707.9 & 6706.0 & 6705.3 \\
\hline \multicolumn{3}{|c|}{ Average FPR } & 6781.6 & & & & \\
\hline \multicolumn{2}{|c|}{ Average } & FPD & 0.640 & \multicolumn{2}{|c|}{7.712} & & \\
\hline
\end{tabular}


Table 10. Freezing point resistance data for Ft. Collins loam soil tes at the 15 atmosphere soil moisture tension lovel.

\begin{tabular}{|c|c|c|c|c|c|c|c|}
\hline \multicolumn{3}{|c|}{ Treatments } & \multicolumn{5}{|c|}{ Successive Freezing } \\
\hline S & FT & $\operatorname{SiT}$ & 1 & 2 & 3 & 4 & 5 \\
\hline P & $\mathrm{NF}$ & 15 & 7186 & 7142 & 7149 & 7139 & 7136 \\
\hline $\mathrm{P}$ & $A F$ & 15 & 7189 & 7151 & 7129 & 7119 & 7104 \\
\hline $\mathrm{P}$ & $\mathrm{DF}$ & 15 & 7202 & 7056 & 7044 & 7035 & 7031 \\
\hline \multicolumn{2}{|c|}{ Average } & FPR & \multicolumn{5}{|l|}{7192} \\
\hline \multicolumn{2}{|c|}{ Average } & FPD & 1.930 & \multicolumn{2}{|c|}{23.256} & & \\
\hline $\operatorname{IIP}$ & $\mathrm{MP}$ & 15 & 7628 & 7530 & 7517 & 7523 & 7489 \\
\hline MP & $\mathrm{IFF}$ & 15 & 7621 & 7542 & 7546 & 7534 & 7511 \\
\hline $\operatorname{INP}$ & $\mathrm{AF}$ & 15 & \multirow{2}{*}{\multicolumn{5}{|c|}{ (Data incomplete) }} \\
\hline $\mathrm{MP}$ & $\mathrm{DF}$ & 15 & & & & & \\
\hline \multicolumn{2}{|c|}{ Average } & $\mathrm{PPR}$ & 7628 & & & \\
\hline \multicolumn{2}{|c|}{ Average } & FPD & 3.227 & \multicolumn{2}{|c|}{38.89} & & \\
\hline
\end{tabular}


Table 11. Freezing point resistance data for Chino clay loam soil 377 at the $1 / 3$ atmosphere soil moisture tension level.

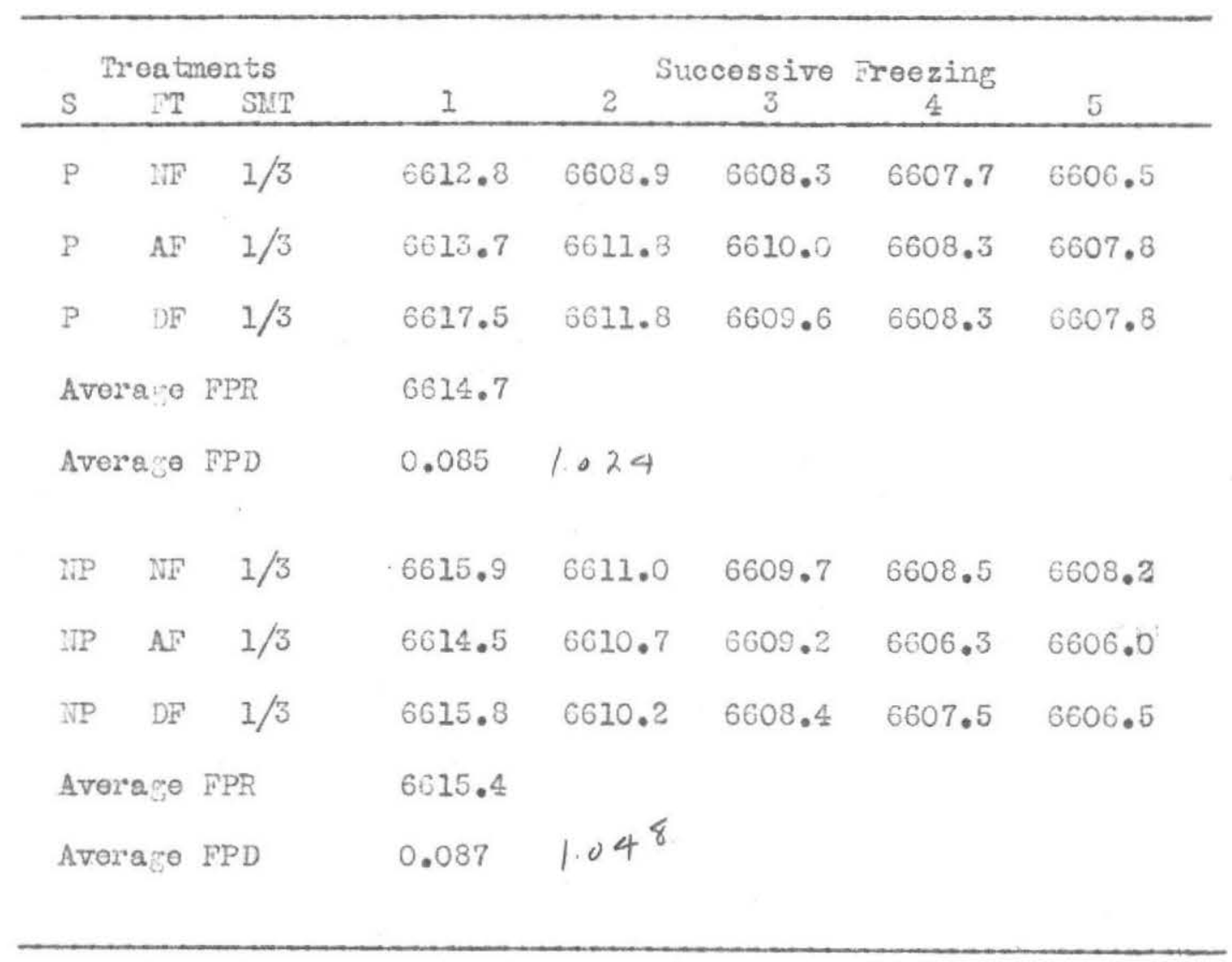


Tablo 12. Freezing point resistance data for Chino clay loan soil 377 at the 1 atmosphere soil moisture tension level.

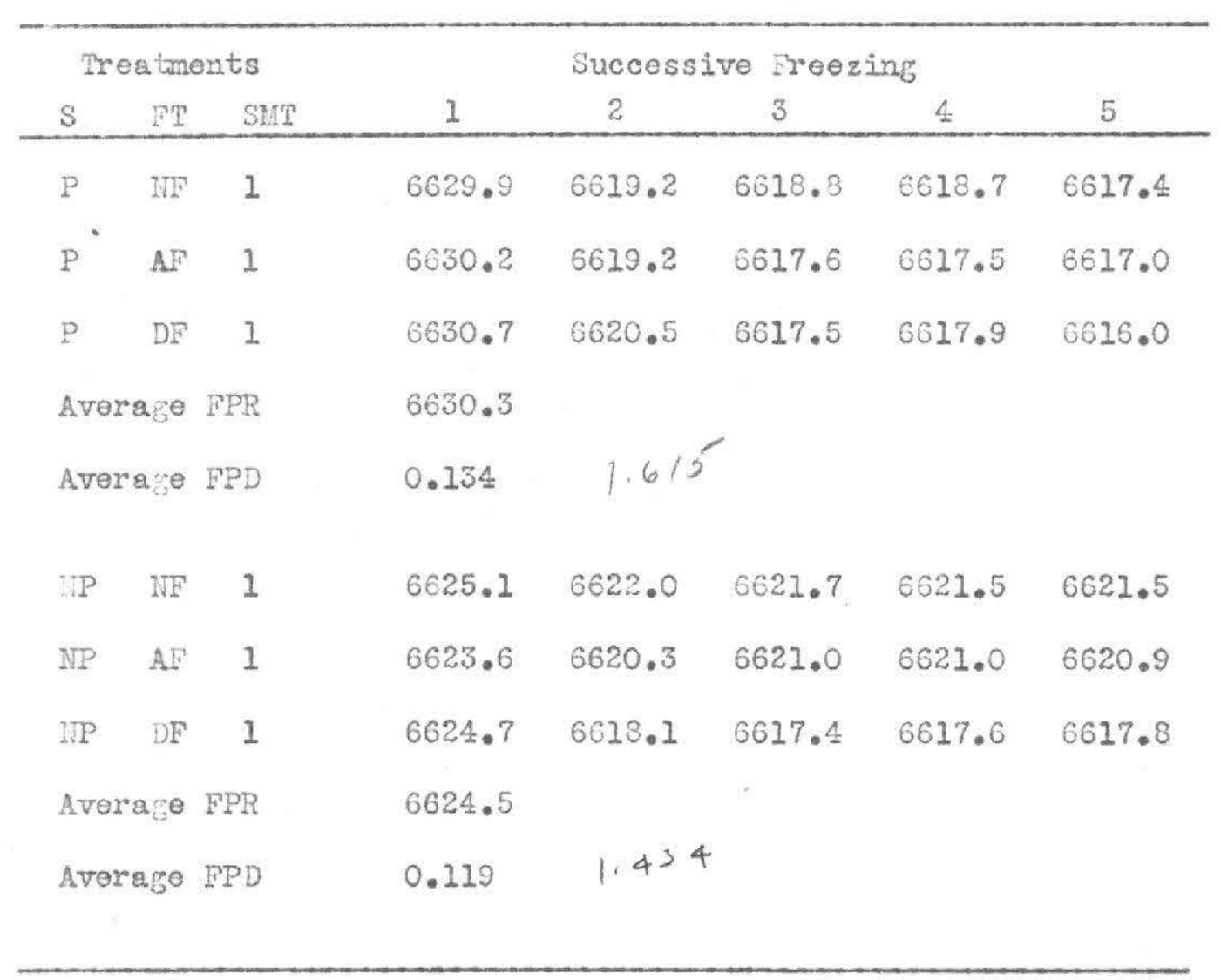


Table 13. Freezing point resistunco data for Chino clay loam soil 377 at the 5 atmosphere soil moisture tension: level.

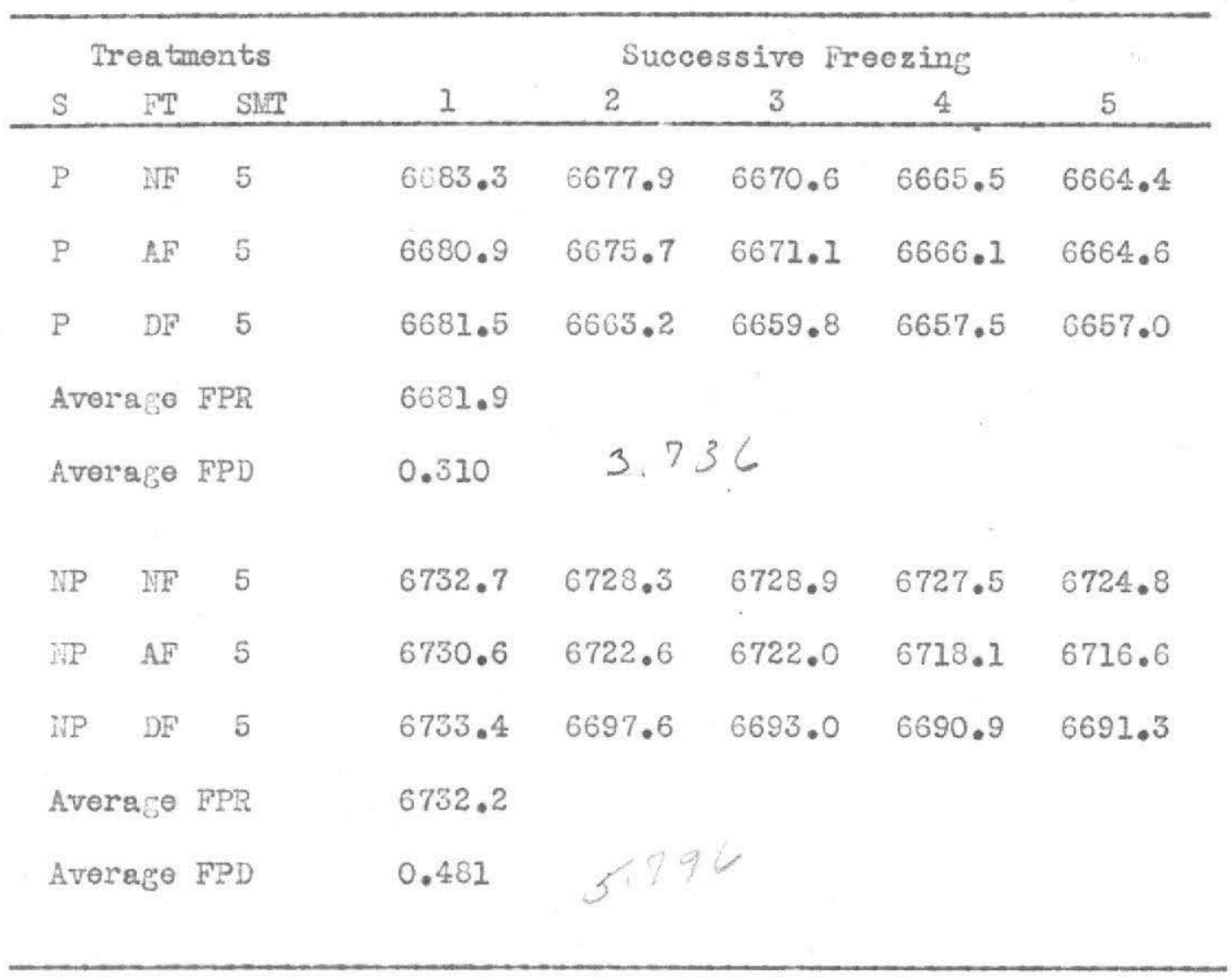


Tajle 14. Freczing point resistance data for Chino clay loan soil 377 at the 15 atmosphere soil moisture tension level.

\begin{tabular}{|c|c|c|c|c|c|c|c|}
\hline \multicolumn{3}{|c|}{ Troatmonts } & \multicolumn{5}{|c|}{ Successive Proezin: } \\
\hline$S$ & $\mathrm{ET}$ & SitT & 1 & 2 & 3 & 4 & 5 \\
\hline $\mathrm{P}$ & min & 15 & 7143 & 7097 & 7059 & 7060 & 7057 \\
\hline P & $A$ & 15 & 7111 & 7065 & 7031 & 7028 & 7029 \\
\hline P & DF & 15 & 7119 & 6986 & 6948 & 6948 & $c 955$ \\
\hline \multicolumn{2}{|c|}{ Average } & FPR & 7124 & \multirow{2}{*}{\multicolumn{2}{|c|}{20.73}} & & \\
\hline \multicolumn{2}{|c|}{ Avera;o } & FPD & 1.722 & & & & \\
\hline $1 . P$ & $\mathrm{M}$ & 15 & 7230 & 7255 & 7228 & 7220 & 7209 \\
\hline AP & $\mathrm{A}$ & 15 & 7250 & 7230 & 7201 & 7198 & 7197 \\
\hline$M P$ & $D F$ & 15 & 7240 & 7038 & 7061 & 7060 & 7056 \\
\hline \multicolumn{3}{|c|}{ Avoraco IPR } & 7257 & \multirow{2}{*}{\multicolumn{2}{|c|}{2563}} & & \\
\hline Ave & $a g$ & APD & 2.130 & & & & \\
\hline
\end{tabular}


Table 15. Analysis of varianco of freezing type and successive froezing treatments at the $1 / 3$ atmosphere soil moisture tension lovel.

\begin{tabular}{|c|c|c|c|c|c|c|c|}
\hline \multirow[t]{2}{*}{ Soil } & \multirow[t]{2}{*}{ SMT } & & & \multicolumn{2}{|c|}{ Puddled } & \multicolumn{2}{|c|}{ Unpuddled } \\
\hline & & & & Variance & $F$ & Variance & $F$ \\
\hline \multirow{7}{*}{3044} & \multirow{7}{*}{$1 / 3$} & Total & 74 & 7.05 & \multirow{3}{*}{0.17} & 9.11 & \multirow{3}{*}{0.38} \\
\hline & & FT & 2 & 3.46 & & 10.58 & \\
\hline & & Rep & 4 & 10.08 & & 29.79 & \\
\hline & & Errorl & 8 & 19.89 & \multirow{4}{*}{$\begin{array}{c}77.98 * * \\
1.95\end{array}$} & 27.06 & \multirow{4}{*}{$\begin{array}{c}24.91 * * \\
0.38\end{array}$} \\
\hline & & & 4 & 65.51 & & 52.38 & \\
\hline & & SFXFT & 8 & 1.64 & & 0.81 & \\
\hline & & Error 2 & 48 & 0.84 & & 2.11 & \\
\hline \multirow{7}{*}{83} & \multirow{7}{*}{$1 / 3$} & Total & 74 & 10.71 & \multirow{3}{*}{$9.54 * *$} & 15.05 & \multirow{3}{*}{2.49} \\
\hline & & $\mathrm{FT}$ & 2 & $59 \cdot 23$ & & 56.86 & \\
\hline & & Rop & 4 & 3.89 & & 29.68 & \\
\hline & & Error 1 & 8 & 6.21 & \multirow{4}{*}{$\begin{array}{r}123.40 * * \\
6.21 * *\end{array}$} & 22.83 & \multirow{4}{*}{$\begin{array}{r}109.10 * * \\
8.13 * *\end{array}$} \\
\hline & & $\mathrm{SF}$ & 4 & 127.11 & & 110.21 & \\
\hline & & SFXPT & 8 & 6.40 & & 8.21 & \\
\hline & & Errore & 48 & 1.03 & & 1.01 & \\
\hline \multirow{7}{*}{377} & \multirow{7}{*}{$1 / 3$} & Total & 74 & 10.28 & \multirow{3}{*}{$11.33 * *$} & 14.47 & \multirow{3}{*}{0.63} \\
\hline & & FT & 2 & 31.49 & & 11.42 & \\
\hline & & Rep & 4 & 17.57 & & 23.94 & \\
\hline & & Exror $_{1}$ & 8 & 2.78 & \multirow{4}{*}{$\begin{array}{c}64.88 * * \\
2.85\end{array}$} & 18.04 & \multirow{4}{*}{$\begin{array}{c}89.20 * * \\
0.90\end{array}$} \\
\hline & & $\mathrm{SF} \perp$ & 4 & 132.29 & & 174.85 & \\
\hline & & SFXFr & 8 & 5.42 & & 1.76 & \\
\hline & & Error2 & 48 & $1.90^{\circ}$ & & 1.96 & \\
\hline
\end{tabular}


Table 16. Analysis of variance of froezing type and successive freezing treatments at the 1 atmosphere soil moisture tension level.

\begin{tabular}{|c|c|c|c|c|c|c|c|}
\hline \multirow[t]{2}{*}{ Soil } & \multirow[t]{2}{*}{ SWTS } & & & \multicolumn{2}{|c|}{ Puddled } & \multicolumn{2}{|c|}{ Unpuddled } \\
\hline & & & & Variance & $F$ & Variance & $F$ \\
\hline 3044 & 1 & $\begin{array}{l}\text { Total } \\
\text { PT } \\
\text { Nop } \\
\text { Error } 1 \\
\text { SF } \\
\text { SFrFT } \\
\text { Error } 2 \\
\end{array}$ & $\begin{array}{r}74 \\
2 \\
4 \\
8 \\
4 \\
8 \\
48 \\
\end{array}$ & $\begin{array}{r}9.60 \\
46.46 \\
23.51 \\
15.28 \\
71.82 \\
9.18 \\
0.67 \\
\end{array}$ & $\begin{array}{c}3.29 \\
107.20 * * \\
13.70 * *\end{array}$ & $\begin{array}{r}42.64 \\
230.01 \\
128.39 \\
202.60 \\
112.95 \\
7.31 \\
1.90 \\
\end{array}$ & $\begin{array}{c}1.13 \\
59.44 * * \\
3.84 * *\end{array}$ \\
\hline 83 & 1 & $\begin{array}{l}\text { Total } \\
\text { PT } \\
\text { Rep } \\
\text { Error } 1 \\
\text { SF } \\
\text { SFxir } \\
\text { Error2 }\end{array}$ & $\begin{array}{r}74 \\
2 \\
4 \\
8 \\
4 \\
8 \\
48 \\
\end{array}$ & $\begin{array}{r}9.54 \\
84.99 \\
1.97 \\
2.56 \\
106.65 \\
0.77 \\
0.56 \\
\end{array}$ & $\begin{array}{r}33.19 * * \\
190.40 * * \\
12.10 * *\end{array}$ & $\begin{array}{r}36.81 \\
606.78 \\
21.70 \\
40.38 \\
177.86 \\
41.35 \\
1.13 \\
\end{array}$ & $\begin{array}{r}14.84 * * \\
157.40 * * \\
36.59 * *\end{array}$ \\
\hline 377 & 1 & $\begin{array}{l}\text { Total } \\
\text { FT } \\
\text { Rep } \\
\text { Error } 1 \\
\text { SF } \\
\text { SExT } \\
\text { Error2 }\end{array}$ & $\begin{array}{r}74 \\
2 \\
4 \\
8 \\
4 \\
8 \\
48 \\
\end{array}$ & $\begin{array}{r}27.32 \\
1.22 \\
4.11 \\
11.75 \\
458.90 \\
2.16 \\
1.17 \\
\end{array}$ & $\begin{array}{c}392.00 * * \\
1.85\end{array}$ & $\begin{array}{r}74.68 \\
70.94 \\
5.15 \\
10.19 \\
56.40 \\
5.12 \\
0.88 \\
\end{array}$ & $\begin{array}{c}6.89 * \\
64.10 * * \\
5.82 *\end{array}$ \\
\hline
\end{tabular}


Table 17. Analysis of variance of freezing type and successive freezing treatments at the 5 atmosphere soil moisture tension level.

\begin{tabular}{|c|c|c|c|c|c|c|c|}
\hline \multirow[t]{2}{*}{ Soil } & \multirow[t]{2}{*}{ SMT } & & & \multicolumn{2}{|c|}{ Puddled } & \multicolumn{2}{|c|}{ Unpuddled } \\
\hline & & & & Variance & $F$ & Variance & $\mathrm{F}$ \\
\hline \multirow{7}{*}{3044} & \multirow{7}{*}{5} & Total & 74 & 681.9 & \multirow{4}{*}{2.67} & 1384.8 & \multirow{3}{*}{3.83} \\
\hline & & BT & 2 & 2048.5 & & 10824.3 & \\
\hline & & Rep & 4 & 1652.6 & & 3709.0 & \\
\hline & & Error 1 & 8 & 767.6 & & 2824.9 & \multirow{4}{*}{$\begin{array}{r}403.50 * * \\
-56.00 * *\end{array}$} \\
\hline & & & 4 & 8135.8 & \multirow{3}{*}{$\begin{array}{r}709.00 * * \\
55.60 * *\end{array}$} & 8279.8 & \\
\hline & & SFXFT & 8 & 63.8 & & 1149.7 & \\
\hline & & Error 2 & 48 & 11.5 & & 20.5 & \\
\hline \multirow{7}{*}{83} & \multirow{7}{*}{5} & Total & 74 & 225.9 & \multirow{4}{*}{$5.54 *$} & 1029.4 & \multirow{4}{*}{$22.20 * *$} \\
\hline & & & 2 & 1118.3 & & 17962.5 & \\
\hline & & Rep & 4 & 704.5 & & 533.2 & \\
\hline & & Error $_{1}$ & 8 & 201.6 & & 808.5 & \\
\hline & & & 4 & 2324.3 & \multirow{3}{*}{$\begin{array}{r}624.80 * * \\
19.17 * *\end{array}$} & 5776.3 & \multirow{3}{*}{$\begin{array}{l}644.67 * * \\
112.20 * *\end{array}$} \\
\hline & & SFXFT & 8 & 71.3 & & 1005.3 & \\
\hline & & Error $_{2}$ & 48 & 3.7 & & 9.0 & \\
\hline & & & & & & & \\
\hline \multirow{7}{*}{377} & \multirow{7}{*}{5} & Total & 74 & 77.1 & \multirow{4}{*}{$29.52 * *$} & 244.8 & \multirow{4}{*}{$24.41 * *$} \\
\hline & & PTT & 2 & 560.3 & & 5061.8 & \\
\hline & & Rep & 4 & 8.4 & & 16.5 & \\
\hline & & Error 1 & 8 & 19.0 & & 20.8 & \\
\hline & & & 4 & 995.2 & \multirow{3}{*}{$\begin{array}{c}581.90 * * \\
24.80 * *\end{array}$} & 1123.0 & \multirow{3}{*}{$\begin{array}{r}192.30 * * \\
61.60 * *\end{array}$} \\
\hline & & SFXFT & 8 & 42.5 & & 359.7 & \\
\hline & & Error2 & 48 & 1.7 & & 5.8 & \\
\hline
\end{tabular}


Table 18. Analysis of variance of freozing type and successive freezing treatments at the 15 atmosphere soll moisture tension level.

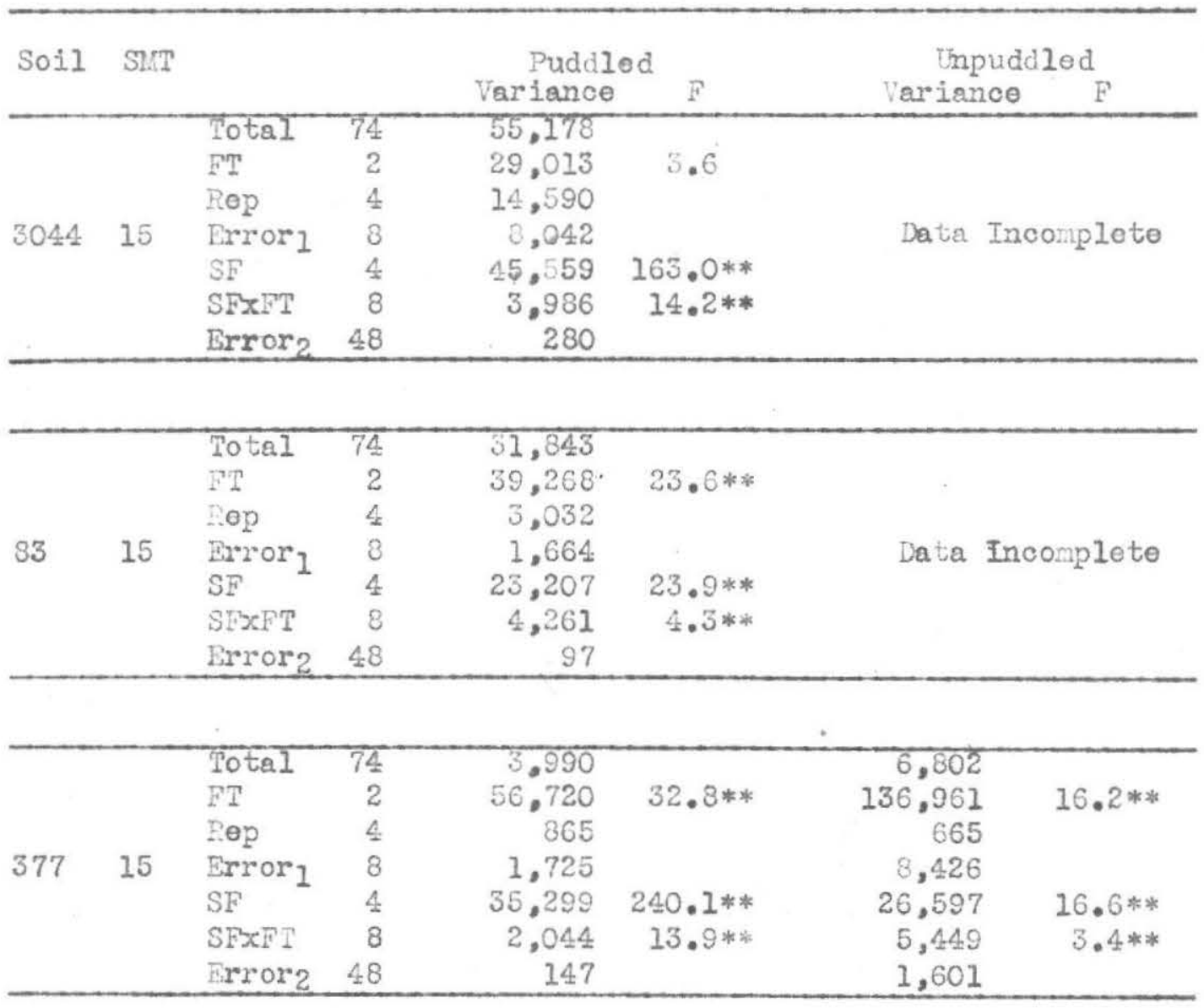


Table 19. Analysis of variance of freezing type and successive freezing at each soil texture, puddling and moisture tension level

\begin{tabular}{|c|c|c|c|c|c|c|}
\hline \multirow{3}{*}{$\begin{array}{l}\text { Soil } \\
\text { Acc. } \\
\text { No. }\end{array}$} & \multirow[b]{3}{*}{ Puddling } & \multirow{3}{*}{$\begin{array}{c}\text { Source } \\
\text { of } \\
\text { variation }\end{array}$} & \multicolumn{4}{|c|}{ Variance ratio } \\
\hline & & & $1 / 3^{4}$ & $1^{9}$ & $5^{9}$ & $15^{4}$ \\
\hline & & & F & F & $\mathrm{F}$ & $\mathrm{F}$ \\
\hline \multirow{2}{*}{3044} & Puddled & $\begin{array}{l}\text { FT } \\
\text { SF' } \\
\text { SFXFT }\end{array}$ & $\begin{array}{c}0.2 \\
78.0^{* * *} \\
2.0\end{array}$ & $\begin{array}{c}3.3^{3} \\
107.2^{k *} \\
13.7^{* * *}\end{array}$ & $\begin{array}{c}2.7 \\
709.0 \% \\
55.6 * *\end{array}$ & $\begin{array}{c}3.6 \\
163.0^{\text {*n }} \\
14.2^{3 \% *}\end{array}$ \\
\hline & Unpuddled & $\begin{array}{l}\text { FT } \\
\text { SF } \\
\text { SFXTT }\end{array}$ & $\begin{array}{c}0.4 \\
24.9^{\text {** }} \\
0.4\end{array}$ & $\begin{array}{l}1.1 \\
59.4^{* * *} \\
3.8 * *\end{array}$ & $\begin{array}{c}3.8 \\
403.5^{* *} \\
56.0^{* * *}\end{array}$ & - \\
\hline \multirow{2}{*}{83} & Puddled & $\begin{array}{l}\text { FT } \\
\text { SF } \\
\text { SFXFT }\end{array}$ & $\begin{array}{r}9.5^{* *} \\
123.4^{* *} \\
6.2^{* *}\end{array}$ & $\begin{array}{r}33.2^{* *} \\
190.4^{* *} \\
12.1^{* *}\end{array}$ & $\begin{array}{c}5.5^{*} \\
624.8^{* *} \\
19.2^{* *}\end{array}$ & $\begin{array}{r}23.6 \% * \\
23.9^{* *} * \\
4.4^{* *}\end{array}$ \\
\hline & Unpuddled & $\begin{array}{l}F T \\
\text { SF } \\
\text { SFXFT }\end{array}$ & $\begin{array}{r}2.5 \\
109.1 * \% \\
8.1 * *\end{array}$ & $\begin{array}{l}14.8 * * \\
157.4 * * \\
36.6 * *\end{array}$ & $\begin{array}{l}22.2^{* * *} \\
644.7 * * \\
112.2^{* *}\end{array}$ & $\overline{-}$ \\
\hline \multirow{2}{*}{377} & Puddled & $\begin{array}{l}\text { FT } \\
\text { SF } \\
\text { SFXFT }\end{array}$ & $\begin{array}{l}11.3^{* *} \\
64.9^{* *} \\
2.9^{*}\end{array}$ & $\begin{array}{c}0.1 \\
392.0^{* *} \\
1.9\end{array}$ & $\begin{array}{r}29.5^{* *} \\
581.9 * * \\
24.8 * *\end{array}$ & $\begin{array}{r}32.9^{* *} \\
240.1^{* *} \\
13.9 \%\end{array}$ \\
\hline & Unpuddled. & $\begin{array}{l}\text { FT } \\
\text { SF } \\
\text { SFXFT }\end{array}$ & $\begin{array}{c}0.6 \\
89.2^{* *} \\
0.9\end{array}$ & $\begin{array}{c}6.9^{*} \\
64.1^{*} * \\
5.8^{*}\end{array}$ & $\begin{array}{r}24.4^{* *} \\
192.3^{* * *} \\
61.6 \%\end{array}$ & $\begin{array}{l}16.2 * * \\
16.6 * * \\
3.4 * *\end{array}$ \\
\hline
\end{tabular}

7 Soil moisture tension level in atmospheres.

$\mathrm{FT}=$ Freezing type, $\mathrm{F}=$ Variance ratio

$\mathrm{SF}=$ Successive freezing

* Significant at 5 percent level (19:1)

*h Significant beyond 1 percent level (99:1) 
Table 20. Pooled analysis of variance of soil texture, pudding, freezing type, and successive freezing treatments at the $1 / 3$ atmosphere soil moisture tension level.

\begin{tabular}{|c|c|c|c|c|}
\hline $\begin{array}{c}\text { Source } \\
\text { of } \\
\text { Veriation }\end{array}$ & $\begin{array}{l}\text { Degrees } \\
\text { of } \\
\text { Freedom }\end{array}$ & $\begin{array}{l}\text { Sums } \\
\text { of } \\
\text { Squares }\end{array}$ & $\begin{array}{c}\text { Mean } \\
\text { syure }\end{array}$ & $\begin{array}{c}\text { F } \\
\text { Value }\end{array}$ \\
\hline Total & 449 & $7,083.77$ & 16.89 & \\
\hline$S$ & 2 & $1,063.67$ & 781.09 & \\
\hline$p$ & 1 & 830.69 & 030.69 & \\
\hline$S x P$ & z & 479.0 & 239.70 & \\
\hline FT & 2 & 45.30 & 22.65 & 1.33 \\
\hline FTXS & 4 & 118.77 & 29.69 & 1.74 \\
\hline $\mathrm{FTxP}$ & $\alpha$ & 34.88 & 17.44 & 1.02 \\
\hline FTX $\mathrm{XXP}$ & 4 & $7 \approx .75$ & 18.19 & 1.06 \\
\hline Error (1) & 72 & $1, \ldots 30.12$ & 17.68 & \\
\hline$S F$ & 4 & $2,441 \ldots 1$ & 610.30 & $435.93 \%$ \\
\hline SFXS & 8 & 128.67 & 16.08 & 11.49 \\
\hline SFXP & 4 & 15.00 & 3.75 & $2.57 \%$ \\
\hline SFXFT & 8 & 70.20 & 8.78 & $6.27 \%$ \\
\hline SFXFTxS & 16 & 90.24 & 5.64 & 4. $02 \%$ \\
\hline SFX TXP & 8 & 6.69 & 0.84 & 0.60 \\
\hline SFXSXP & 8 & 28.99 & 3.62 & $-.58 * *$ \\
\hline SFXFTXSAP & 16 & 3.91 & $1 . x y$ & 1.60 \\
\hline Error (2) & 288 & 403.28 & 1.40 & \\
\hline
\end{tabular}


Table 2l. Pooled analysis of variance of suil texture, pudiling, freezing type, and successive freezing treatments at the $I$ atmosphere soil moisture tension level.

\begin{tabular}{|c|c|c|c|c|}
\hline $\begin{array}{c}\text { Source } \\
\text { of } \\
\text { Variation }\end{array}$ & $\begin{array}{l}\text { Degrees } \\
\text { of } \\
\text { Preedom }\end{array}$ & $\begin{array}{c}\text { Sums } \\
\text { of } \\
\text { Sguares }\end{array}$ & $\begin{array}{l}\text { Hean } \\
\text { Square }\end{array}$ & $\begin{array}{c}\vec{F} \\
\text { Value }\end{array}$ \\
\hline Total & 449 & $34,858.87$ & 77.59 & \\
\hline $\mathrm{S}$ & 2 & $7,775.81$ & $3,887.01$ & \\
\hline $\mathrm{P}$ & 1 & $11,736.13$ & $11,136.16$ & \\
\hline SxP & 2 & $5,415.07$ & $2,706.53$ & \\
\hline FT & 2 & $1,138.68$ & 569.19 & 13.57 난. \\
\hline FTxS & 4 & 450.22 & 112.56 & $2.67 *$ \\
\hline FTxP & 2 & 235.72 & 117.86 & 2.81 \\
\hline FTXPXS & 4 & 253.17 & 6.29 & 1.00 \\
\hline Error (1) & 72 & $3,019.17$ & 41.93 & \\
\hline SF & 4 & $3,393.15$ & 848.78 & $816.13 x+4$ \\
\hline SFXS & 8 & 104.72 & 13.09 & $12.58 \%$ \\
\hline SFXP & 4 & 73.21 & 18.30 & $17.54 * 4$ \\
\hline SFXFT & 8 & 374.47 & 46.81 & $45.00 \div 2$ \\
\hline$S F \times S \times P$ & 8 & 365.73 & 45.72 & $43.96 \ldots$ \\
\hline SFXPTXS & 16 & 98.31 & 6.14 & $5.90 *-x$ \\
\hline SFXFTXP & 8 & 42.81 & 5.35 & $5.14 * *$ \\
\hline SFXFTXSXP & 16 & 62.50 & 3.91 & $3.75 * * x$ \\
\hline Error (2) & 288 & 300.30 & $1 .(4$ & \\
\hline
\end{tabular}


Trble 22. Pooled tnalysis of variance of soil texture, pudding, freezing type, and successive freezing treatments at the 5 atmosphere soil moisture tension level.

\begin{tabular}{|c|c|c|c|c|}
\hline $\begin{array}{c}\text { Source } \\
\text { of } \\
\text { Variation }\end{array}$ & $\begin{array}{l}\text { Degrees } \\
\text { of } \\
\text { Freedom }\end{array}$ & $\begin{array}{c}\text { Sums } \\
\text { of } \\
\text { Squares }\end{array}$ & $\begin{array}{l}\text { Wean } \\
\text { Syucre }\end{array}$ & $\begin{array}{l}\text { F } \\
\text { V. lue }\end{array}$ \\
\hline Total & 449 & $1,3 \cup 6,533$ & $2, y 77$ & \\
\hline$S$ & 2 & 324,497 & $162, \approx 49$ & \\
\hline p & 1 & 688,043 & 688,043 & \\
\hline $3 \times P$ & 2 & 32,937 & 26,468 & \\
\hline FT & 2 & $0 \pm, 781$ & 17,590 & $2 \mathrm{C} * *$ \\
\hline JXS & 4 & 5,843 & 1,461 & 2 \\
\hline FNPP & 2 & 29,907 & $14,05 \cdot x$ & $17 * x$ \\
\hline FTXP & 4 & 4,619 & 1,155 & 1 \\
\hline Trror (1) & 72 & $6 ., t .34$ & 584 & \\
\hline SF & 4 & $89,-31$ & $2: 4,477$ & $1,605 \%$ \\
\hline SFXS & 8 & 14,553 & 1,819 & $130 *-$ \\
\hline$S F \times P$ & 4 & 951 & 238 & $17 \% *$ \\
\hline$S F \times F T$ & 8 & 14,070 & 1,054 & $13 *$ \\
\hline SIXSxP & 8 & $1,0 \leq 0$ & 130 & $9 \times-6$ \\
\hline SFXFTXS & 16 & $I,+C c_{2}$ & 69 & Uस: \\
\hline$S F \times T x P$ & 4 & 4,012 & 001 & $35 *$ \\
\hline SFXFTXSXP & 16 & 1,739 & 108 & $8 \div *$ \\
\hline Error (4) & 288 & 4,07 & 14 & \\
\hline
\end{tabular}


Table 23. Surmary of analysis of variance where the error has been pooled for analysis at three soil moisture tension levels.

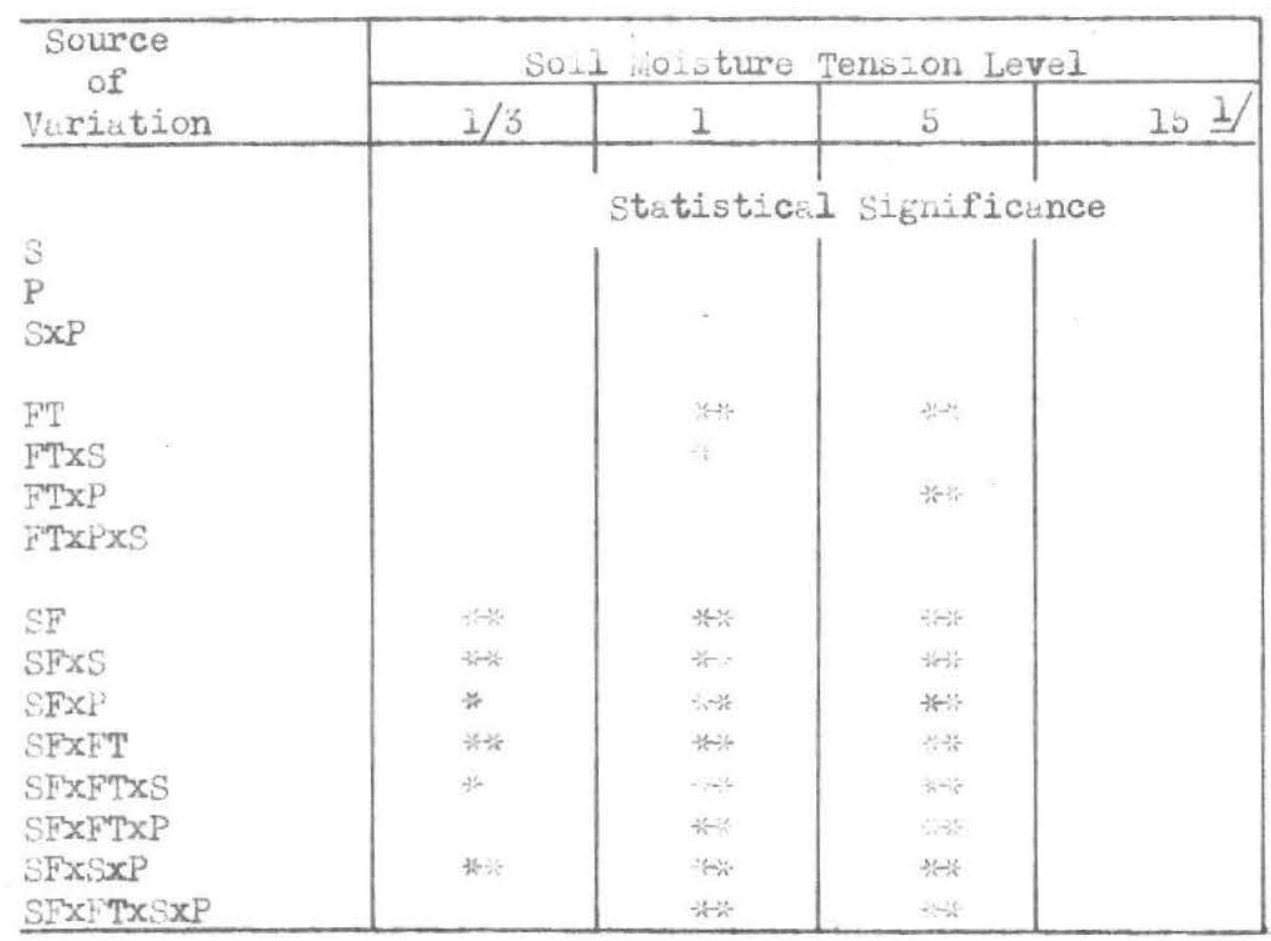

If Data were not sufficiently com lete for analysis. * Significant at 5 percent level (19:1).

* Significant beyond 1 percent lovel (y9:I). 